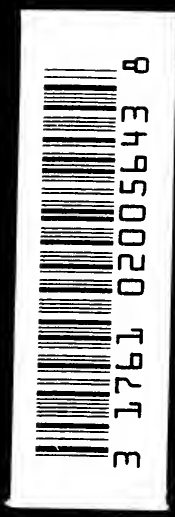




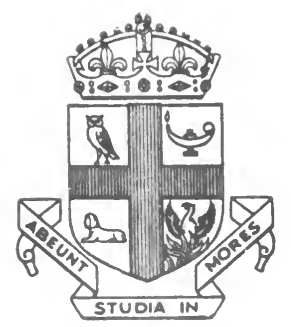

THE LIBRARY

of

VICTORIA UNIVERSITY

Toronto 
a.j.Bell.

vichnie 6rlleq2. 

$=$ 

DOMESTIC MANNERS

OF

SIR WALTER SCOTT. 




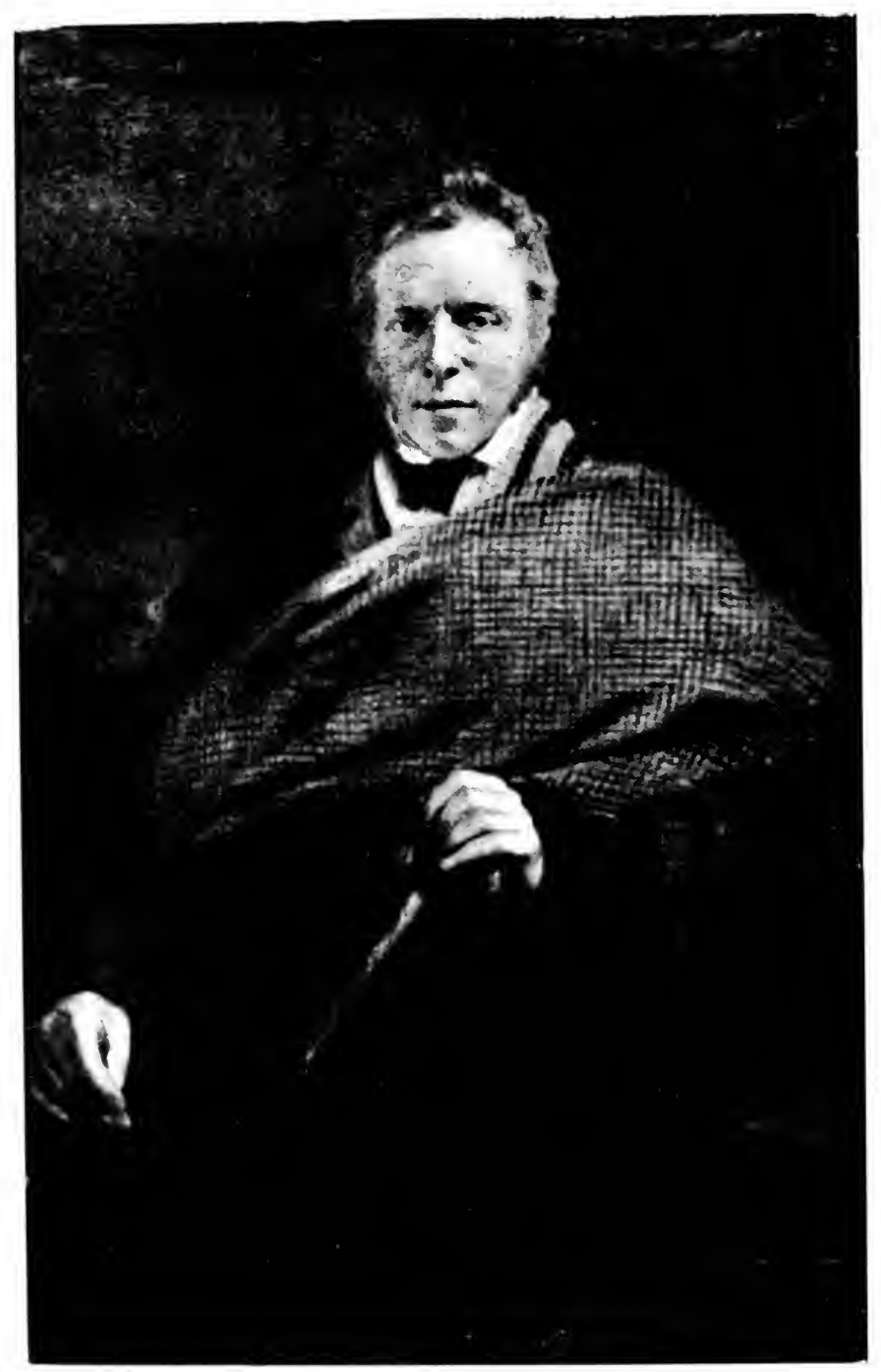

James Hogg, 'The Ettrick Shepherd.'

by kind permission of Messrs, Blackwood \& Sons, Edinburgh. 


\section{DOMESTIC MANNERS}

\section{OF \\ SIR WALTER SCOTT}

BY

JAMES HOGG, The "Ettrick Shepherd,"

MEMOIR OF THE ETTRICK SHEPHERD

BY THE

REv. J. E. H. THOMSON, D.D.

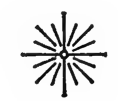

STIRLING :

ENEAS MACKAY, 43 MURRAY PLACE.

1909. 


$$
\begin{aligned}
& \text { PR } \\
& 5335 \\
& H 58
\end{aligned}
$$




\section{CONTENTS.}

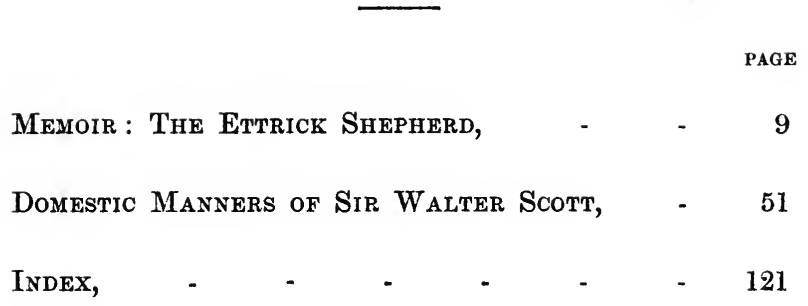





\section{MEMOIR : \\ LIFE OF THE ETTRICK SHEPHERD.}

$\mathrm{F}$

EW parts of Scotland have been more glorified by the Muses than has the Ettrick Forest, with its twin streams, the Ettrick and the Yarrow. Wherever the English language is spoken or its literature read will Wordsworth's "Yarrow Revisited" be prized; wherever Lowland Scots is sung will the sorrows of Ettrick, made desolate by Flodden, find a voice in "The Floo'rs o' the Forest." Among its round and grassy hills, hiding in its bosky dells, the Queen of Faery has held her court, nay, held converse with men whose memory was yet fresh in the beginning of last century. At the middle of the century preceding, witches and warlocks, wraiths and warnings, were common, and elves and brownies far from rare. It was the chosen home of ballad poetry, especially that of the weird and mysterious sort. Some of the most romantic figures in Scottish history have been connected with Selkirkshire in critical points in their career. After his victory of Stirling Bridge, Wallace met the notables of Scotland in St. Mary's Kirk, and was chosen by them Guardian of the Realm. Near where the Yarrow joins the Ettrick is the fatal field of Philiphaugh, which 
put a period to the victories of the ill-fated Montrose. Given but a suitable soil in the soul of the youth, these were the surroundings to foster the growth of romance and poetry.

There is, however, another side to this picture. While to one who in the height of summer drives along the beautiful tree-sheltered road that follows the course of the Yarrow or the Ettrick everything presents visions of quiet loveliness, verdant holms embraced by softly murmuring streams, and shaded by full-foliaged trees, further up both valleys become much barer. This bleakness and bareness were more pronounced less than a century ago. Washington Irving, who visited Sir Walter Scott in the month of August, 1816, and was taken by him to some height which commanded an extensive prospect, tells how his host pointed out place after place famous in Border legend or poetry. While Sir Walter was going on with his localisation of poetic memories, Irving confesses: "I gazed about me with mute surprise; I may say disappointment. I beheld a mere succession of grey waving hills, line beyond line as far as my eye could reach, monotonous in their aspect, and so destitute of trees that one could almost see a stout fly walking along their profile; and the far-famed Tweed appeared a naked stream flowing between hills, without a tree or a thicket on its banks."

Quarter of a century earlier we have in the first "Statistical Account of Scotland" a description of the Parish of Ettrick, by the Rev. Robert Russell, the then recently appointed parish minister, afterwards Dr. 
Russell, of Yarrow. He declares the district to be desolate in the extreme: it is made up of hills, mostly bare-the few trees mainly pines-little agriculture, few crops reared, and these only come to perfection in hot dry years. There are only 17 ploughs and 20 carts in the parish; no waggons or carriages. The roads are almost impassable, the bridges few and in bad repair. The best road is that to Selkirk, which is so indifferent that although the distance is only sixteen miles it takes a horseman four hours to traverse it. Snow is at times a great inconvenience. The writer says: "Often for many months at a time we can have no intercourse with mankind." The whole scene is one of chill, mist, and misery-grey, inhospitable hills, treacherous bogs, and roaring, impassable streams. In winter, when snow or sleet are not falling in driving, drifting showers, the landscape is covered with a hard mail of ice or a soft garment of snow in mountainous wreaths. On it all the melancholy face of the incumbent looks out from a window of his somewhat dilapidated manse. The truth is, Mr. Russell had come from being tutor in the house of Napier of Merchiston Hall, where for four years he had been meeting distinguished society. The change from the fertile carse to the wilds of Ettrick was a violent one.

From the end window of his manse Mr. Russell could see, a little way down the side of the Ettrick water, between his house and the parish school, a thatched cottage-a hovel, rather, it would be called now. The thick walls, built of rough irregular stones, cemented 
with clay, were pierced by a door and two windows. The low doorway admitted the visitor to a short narrow passage, with the kitchen to the one hand and the ben room to the other. This was the farm house of Ettrickhall, where lived Robert Hogg and his wife, Margaret Laidlaw. Robin was a somewhat notable man in the parish-the only ruling elder. He had begun life as a shepherd, but having saved a little money, he determined to be a store farmer on his own account, and took the two adjacent small farms of Ettrickhall and Ettrickhouse. To sheep farming he added dealing in sheep, and sold many flocks in the markets at St. Boswells and Carlisle. At first he succeeded pretty well, but a fall in prices, accompanied by the absconding of his principal debtor, made him bankrupt. Everything he possessed was sold by public auction, and he would have been reduced to penury had the neighbour who took the farms not proved a friend, and continued Robin in occupation as his grieve. Although now so humble, Hogg seems to have been of respectable ancestry. Professor Veitch claims for the Hoggs a Scandinavian descent, and is confident that not merely the name, but the personal appearance of those who bore the name, confirmed this opinion. Robert himself claimed to have a connection with the Hoggs of Fauldshope, hereditary vassals of the Scotts of Harden.

His wife was a remarkable woman; she was to a great extent self-taught. Her mother dying when she was quite a child, she, as eldest daughter, had to leave 
school and assume the responsibilities of housemother. By and bye she began to feel painfully her inferiority to her younger brothers and sisters. After an interval of tears and despondency, she set herself vigorously to the study of the Scriptures, and by this means remedied the defects of her education. As she had a vivid imagination and a retentive memory, she eagerly heard, and scrupulously retained, the legendary ballads that were floating about the Border district-many of these, it is to be feared, perished with her death.

This couple were the parents of Tames Hogg, the Ettrick Shepherd. He, their second son, was born in the end of November, 1770. Although his home was so near the parish schoolhouse, James only had some three months' teaching, as the financial disasters to which we have referred had rendered it necessary that he, little mite of seven as he was, had to be hired out to herd cattle. In his autobiography he tells us that his wages were a lamb and a pair of shoes. There, on the solitary hillside, the child-poet conjured up opponents, against whom he ran races, and to outstrip whom he threw off article after article of his scanty clothing; thus, naked and triumphant, he continued his herding till some one collected his scattered garments. The following winter he had another three months of education, when there was an unsuccessful effort to introduce him to the mysteries of penmanship, and this ended his education so far as tuition was concerned. There were, however, other educational influences at work. His elder brother presents us with a picture of 
home life which explains much: we see the housemother while baking, spinning, sewing, chant over the wild, legendary ballads that she had heard from old chroniclers of the past; or tell the weird traditions of wraiths, kelpies, brownies, fairies, and witches that filled the Border air with mystery. Sometimes she repeated the metrical Psalms to her boys, and taught them to repeat them. James, especially, was ready and receptive, and could repeat these before he could read. We can see the eager blue-eyed urchin following breathlessly now the ballad of "Auld Maitland," and now the tales of "Wallace Wight," or of the hard times when there were snow storms and floods in the hills, while his golden hair assumed a more ruddy hue in the glow of the peat fire. Her predilection for the mysterious and supernatural Mrs Hogg probably inherited from her grandfather, William Laidlaw, commonly called Will o' Phaup, famous not only for feats of agility and strength, but also as the last man who had seen the fairies.

The religious history of Ettrick during the 18th century had been a somewhat peculiar one. Enshrined in the memory of all the old people of Hogg's boyhood stood the figure of Thomas Boston, minister from 1707 to 1732, and he, as a theologian, exercised a profound influence on lowland Scotland and the north of Ireland. In every farm house where there was any tincture of religious culture were to be found one or more of Boston's works. Hogg has introduced him into his ballad of the "Pedlar"-_"The minister there 
was a body o' skill." Succeeding him there had been, till the short incumbency of Mr. Russell, no less than eight ministers, most of whom seem to have fallen before the temptation of qualifying their solitude by potations. Potts, the last of them, especially on one occasion, scandalised the natives by mounting a turf dyke in a state of high inebriation, fancying himself on horseback, and urging his steed on with his wig as a riding whip. He was minister in Hogg's boyhood; but he was relieved of the duties of his office, though allowed to retain half the stipend. Notwithstanding these untoward influences there was a deep vein of piety in the natives of Ettrick, a vein which Hogg also possessed.

After this last quarter of education, the early spring saw Hogg again herding cattle. Here he fell in with a rosy maiden, some half-a-dozen summers his senior, and boyishly admired and loved her. After their frugal dinner he was wont to lay his head in her lap and pretend to fall asleep. One day he heard her say, "Puir little lad; juist tired to death." Then he tells us such was the effect of this sympathy on him that he wept till he was afraid she would feel the warm tears trickling on her knee. That fine sensibility showed the incipient poet.

After this he served with nearly a dozen masters in course of fifteen years. One incident in this period is worthy of mention. Having saved five shillings, he expended them on a violin. On this he sawed away at all the tunes he knew, and thus, not a little to the dis- 
comfort of his auditors, he consoled himself for his hard lot. A fiddler at a dance in a farm where Hogg was employed as shepherd, going out to the farm court, was amazed to hear the airs he had just been playing grotesquely imitated by some unseen and unlocalisable musician. Thinking he was a victim of Satanic attentions, he fled for refuge back to the farm kitchen in a state of abject terror. The farmer relieved his mind by telling him the source of these mysterious sounds.

Towards the end of this period he was shepherd with three farmers in succession of the name of Laidlaw, all more or less distant relatives of his mother. With the first of these he stayed eighteen months; with the second two years; but with the third he remained ten years. While with the second of these Laidlaws, Hogg became acquainted with Blind Harry's "Wallace" and Ramsay's "Gentle Shepherd." Strange to say, two things proved stumbling blocks to him-that they were in rhyme and in Scots. At the same time he enjoyed them greatly. When, however, he went to Blackhouse, the farm of the third of those Laidlaws, he was free of a more extensive collection of books, which comprised most of the greater English classics. Even a greater boon to him was the friendship which sprung up between him and William Laidlaw, the son of his master. Much better educated and more extensively read than the Shepherd, he yet recognised the presence of genius, and so, readily put what store he had of information and culture at the service of his less-favoured friend. One 
thing he urged on Hogg, which the poet would have been well to have yielded to - that was, careful polishing of his verses. Hogg preferred to try to do better next time.

During these ten years, from 1790 to 1800 , Hogg not only occupied himself with the study of books and music; he became a noted athlete. A local poetical broadside, descriptive of the prowess of the different competitors in some games in the upper ward of Lanarkshire, had a verse like this :

“'The Ettrick poet he cam' owre,

A cliftie, clever chiel, man ;

But Jamie Battie frae Daebeth,

Beat him by half a heel, man."

Dr. Russell, of Yarrow, quotes from a local poet of Innerleithen a verse which shows that Hogg's interest in these contests continued long after he had ceased to be a contestant. Hogg evidently was of Plato's opinion, that gymnastics as well as music was needed if a man were to be truly educated. Certainly his occupation of shepherd implied the possession of no ordinary amount of agility and endurance. Every sense had to be in keenest exercise, and every bodily faculty had to be ready for work, if one would be a successful shepherd.

In this period he began to compose verses. In the year 1796, as he tells us in his autobiography, he commenced writing verses, and was proud of the title given him of "Jamie the Poeter." These 
songs and ballads were intended to be sung by the milk-maids and other lasses about the farms. Composed and adjusted wholly in the mind of the poet, committing them to writing was a matter of great difficulty. We have above referred to the unsuccessful attempt to teach Hogg writing when he enjoyed that last quarter of tuition; he afterwards remedied this by copying the italic letters, and did at length achieve a legible script. He tells us how he improvised a notebook from a few sheets of paper stitched together, and, filling a phial with ink, which, having corked, he fastened by a string to his waistcoat, he had now but to secure a quill pen to go to the hills fully prepared for the visit of the Muse. When in the house the necessity of writing came upon him, he threw off coat and vest, as if to set about shearing sheep on a hot day; every few lines he had to stop with a cramped wrist. Later, his habit was to write the verses as they came to him on an ordinary school slate; then when the slate was full to engross them in his improvised note books to be ready for publication.

During the year 1797, while he was herding his sheep on the hillside one summer's day, a half-witted man, called John Scott, came to him, and to amuse Hogg repeated the whole of "Tam o' Shanter." He did not allow his visitor to leave him till he could repeat from his lips the whole poem. Scott informed him that it was the work of Robert Burns, of whose existence Hogg then heard for the first time. Burns had died the previous summer. Hogg felt himself in some sort his destined successor. This idea was the 
more fostered by a mistake Hogg had made as to the date of his own birth. He fancied he was precisely twelve years the junior of the Ayrshire bard-that he was born on the 25th of January, 1772-whereas he must have been born fourteen months earlier. The admiration he had for the poem which he had just heard, combined with his consciousness of his own powers, induced feelings similar to those with which Correggio first saw the paintings of Raphael. Hogg felt he could say, "I also am a poet." While his genius made his right to the succession indisputable, his want of education and of the self-judgment which results from it rendered him incapable of revising his work, though this, as we have seen, was urged on him by his friend Laidlaw; hence his productions are so unequal.

When this period of his stay with the Laidlaws of Blackhouse was drawing to a close he published for the first time one of his songs, "Donald Macdonald." We shall give the first two verses:

"My name it is Donald Macdonald,

I leeve in the Hielands sae grand,

I hae followed our banner, and will do

Wherever my Maker has land.

When rankit amang the blue bonnets

Nae danger can fear me ava,

I ken that my brethren around me

Are either to conquer or fa'.

Brogues an' brochin an' $a$ ',

Brochin an' brogues an' a',

$\mathrm{An}^{\prime}$ isna her vera weel aff

Wi' her brogues an' brochin an' a' 
"What though we befreendit young Charlie?

Tae tell it I diuna think shame, Puir lad, he cam' tae us but barely,

An' reckoned oor mountains his hame.

Tis true that oor reason forbad us,

But tenderness carried the day :

Had Geordie cam' friendless amang us

Wi' him we had a' gane away.

Sword an' buckler an' a',

Buckler an' sword an' a',

Noo for George we'll encounter the devil

Wi' sword an' buckler an' a'."

"The first time I sang it," says Hogg in his autobiography, "was to a party of social friends in the Crown Tavern, Edinburgh. They commended it, on which I proffered it to one of them for his magazine. He said it was much too good for that, and advised me to give it to Mr. John Hamilton, who would set it to music and get it engraved. I did so, and went away again to the mountains, where I heard from day to day that the popularity of my song was unbounded; and yet no one ever knew or enquired who was the author." Hogg further tells how, when a Mr. Oliver sang it in the hearing of the Earl of Moira, the Earl was so charmed with it that he proffered the singer his whole influence in Scotland, but never thought of enquiring about the author. It seems there was a General MacDonald, who, imagining the song was about himself, had it sung every day at his mess, and, snapping his fingers, joined enthusiastically in the chorus; yet neither he nor any of 
his officers ever knew, or apparently cared to know, who had written it.

The popularity of "Donald Macdonald" emboldened Hogg to another poetical venture. He had brought a number of sheep to the Edinburgh market for sale, and finding time hang heavy on his hands, he determined to write down from memory some of his songs, and have them printed and published at his own risk. Having found a printer, he carried his intention into effect, and then, having disposed of his sheep, took his departure for the hills again. Never was poetry ushered into the world more recklessly than was this poetical pamphlet, for it was no more: none of the anxious care of correcting the press bothered our happy Shepherd. The result, as might be expected, was disappointing. The poet was mortified to find some stanzas omitted, others misplaced, and every page disfigured with typographical blunders. Although one of the compositions which formed this casual concourse of poetical atoms had the honour of being copied in some of the periodicals of the day, the poet himself declares the whole to have been sad stuff.

In the same year, when the Shepherd made this unlucky plunge into literature, two things occurred which had a great influence on Hogg's future life: he read Scott's "Minstrelsy of the Scottish Border," and, more important still, met Scott himself. When he read the "Minstrelsy" he tells us he was dissatisfied with the imitations he found there of the ancient ballads, and proceeded to produce what he thought 
worthier imitations. In "The Domestic Manners of Sir Walter Scott," reprinted in the present volume, Hogg gives an account of his first meeting with the "Wizard." We shall leave our readers to his account of this. From this booklet may be gathered the kindly, almost fraternal interest Scott took in this child of genius, whom circumstance had so little favoured, and with what freedom Hogg availed himself of Scott's advice and aid. On the other hand, Hogg's admiration for Sir Walter, notwithstanding occasional outbursts of petulance, amounted almost to idolatry.

Although Hogg was a poet he was also a shepherd, and, like most lowland shepherds, was filled with the desire to be a farmer on his own account. He paid more than one visit to the Highlands, and in the course of one of them had reached Harris. As during his

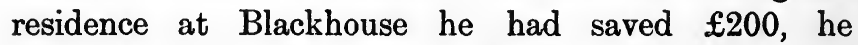
determined to take a sheep farm in the Island of Harris. In prospect of this he penned his farewell to Ettrick. This scheme fell through on account of some legal difficulty, and the result was that our Shepherd lost all his savings. One cannot but feel thankful to Providence for this misfortune. Had Hogg's plans succeeded we should have had a well-to-do Harris farmer the more, but literature would never have been enriched with "Bonnie Kilmeny." Buoyant by nature, Hogg did not lose hope, but betook himself to his crook again, and hired himself to a Nithsdale farmer, Mr. Harkness, of Mitchelslack, and he was sent to keep sheep on a lonely height called Queensberry Hill. For 
miles all round there was no human habitation, nor even a pathway, save sheep tracks; rarely did any wanderer intrude upon the solitude. Here, thus cut off from neighbours, Hogg allowed his clothes to become ragged, and was content to live in a bothy so primitive that he could only enter it on all fours, and when within could not stand upright, but could only squat on the floor. There he was surprised and inspirited by a visit from Allan Cunningham and his brother. Allan was then a stonemason, but had already written some songs, and felt in him the power of penning more. There, in this solitude, were composed most of the pieces which form "The Mountain Bard." This was published for Hogg by Constable. Notwithstanding that Hogg came to him with the introduction of Sir Walter Scott, Constable demurred till the poet agreed to get subscriptions for two hundred copies. These, with the help of Scott, he succeeded in getting. The ballads that make up this collection are very unequal; all are too long.* Although Hogg was so familiar with the genuine ballads, he never seems to have comprehended how much of their charm lies in the condensation and reticence which characterise the finest of them, notably the "Twa Corbies," to which he

* It was in connection with "The Mountain Bard" that Hogg paid that visit to Scott's Edinburgh house, of which Lockhart gives such a ludicrous description. Because Mrs. Scott, who was delicate, was reclining on a couch, the Shepherd threw himself at length on another, and at dinner increased in familiarity with Scott, till he was calling him "Wattie." There probably was some truth in the story, but Lockhart 
refers as having suggested the ballad with which he opens. In spite of its defects, there are not a few beautiful verses in "The Mountain Bard," as for instance the opening verses of the "Pedlar:"-

“'Twas late, late, late on a Saturday's nicht,

The moon was set an' the wind was lown, The lazy mist crap down frae the height

An' the dim blue lowe glimmered laigh on the downe.

"O'er the rank scented fen the bleeter was warping,

High on the black muir the foxes did howl, All by the lone hearth the cricket sat harping,

An' far on the air came the notes of the owl."

The picture is perfect in its "eeriness," and so in its preparation for the intervention of the supernatural. Unlike poetry in general, "The Mountain Bard" was a commercial success. Almost simultaneously Hogg achieved success in a literary work of a totally different character. This was "The Shepherd's Guide." It was a practical treatise on the diseases of sheep, with advice as to the breeds of sheep most suitable for the different soils and climatic conditions. It professed to be written by a shepherd for shepherds. The result of the two

was an artist in mischievous fiction. Laidlaw, criticising another story in which Hogg was represented as addressing Scott as "Wattie," said he never became more familiar than to call him "Shirra." Hogg said of Lockhart that he never told the truth but once, and that was by accident. Lockhart was a child when Hogg's visit occurred, moreover, when he wrote his account of it, he was enraged at the publication by Hogg of "The Domestic Manners of Sir Walter Scott." 
literary ventures was such that Hogg found himself in possession of $£ 300$. Of this more than $£ 200$ was due to "The Mountain Bard."

The possession of so much money wrought a madness in the mind of the Shepherd. Such a sum seemed inexhaustible. The consequence was that he involved himself in farming speculations in Dumfriesshire, so unfortunate, that in less than three years he was once more penniless. He returned to Ettrick and offered himself for hire as a shepherd, but not a man would engage him. His case was the reverse of that in the parable: because he had mismanaged his own, no one would entrust to him any other's wealth. With characteristic philosophy Hogg recognised that the unfortunate result of this last speculation was a cloud that had a silver lining. He now definitely determined to devote himself to literature.

He hastened to Edinburgh, and got Constable to publish for him the "Forest Minstrel," containing, though he himself spoke slightingly of them, some of his very best songs. It did not prove a monetary success, but the Countess of Dalkeith, to whom the volume had been dedicated, presented the bard with

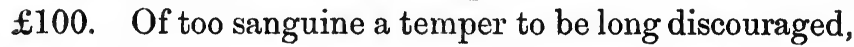
Hogg determined to start a periodical devoted to belles lettres, and the criticism of society and social manners. One cannot feel much surprise that printers and publishers fought shy of such a venture: a rough shepherd setting himself up as the arbiter of politeness and etiquette! Was there ever a greater absurdity? 
After considerable difficulty, he got a genial, but somewhat drouthy bookseller to undertake the onus of publishing the Spy, as Hogg called his paper. The first few numbers were well taken up; but, unluckily, he was guilty of admitting something that to the fastidious taste of Edinburgh seemed indecorous. The result was a sad falling off in the subscribers. Nevertheless, the Spy continued for a whole year. During the course of the life of this unlucky periodical Hogg had two publishers. Robertson, as hinted above, was fond of a "dram," and the printers he employed were like himself. Hogg had to join in their potations, but did not relish it. He tried to limit his share of the liquor consumption, but, notwithstanding, he frequently found himself giddy on leaving these symposia; and, to quote his own words, "the worst thing of all was, I felt that I was beginning to relish it." It is a Rembrandtesque picture-the dusky house in the Cowgate, its dusty, cobweb-covered windows admitting but a small portion of the scant light that reached them; the rubicund, untidy Robertson; the lean, dirty printers; and the fresh-coloured, bright-eyed shepherd, engaged in compiling the Spy, in intervals of lunching on rolls and whisky. One cannot avoid noting here the difference between the real James Hogg afraid of drink getting the mastery of him, and the drouthy. "Shepherd": of the "Noctes Ambrosianæ." Seeing, as he says, that this association was "leading him straight to the devil," he resolved to break with Robertson and employ another printer. The result of 
the whole thing was that, at the end of the year, the Aikmans, his new printers, so far from handing over any money to him, put in a claim for more, to cover half the loss which they alleged they had sustained. This was the end of the Spy. It, however, drew Hogg into association with several literary people who were of use to him. Several of these had aided him in filling the columns of his reckless literary venture. One of them was Robert Sym, the uncle of Professor Wilson, in whom readers of the "Noctes" will recognise "Timothy Tickler."

After occupying himself with a debating society called the "Forum," he published the "Queen's Wake," the work on which his fame chiefly rests. Some of the poetical pieces which had appeared in the Spy struck the taste of his friend Grieve as excellent, and as there was an increased interest in poetry at the time, he urged Hogg to try his fortune with a volume of verse. In consequence he set about collecting the poems he had by him; but in order to give more unity to the composition, he devised the scheme of Queen Mary, newly arrived from France, welcoming the bards of her native land. As each bard repaid by song the hospitality of the royal lady, Hogg had the opportunity of reproducing his various ballads. This was the origin of the "Queen's Wake." With his marvellous facility for composition, a few months sufficed to construct the framework. After it was composed and compiled, he had to get a publisher. Constable fought shy of the business, but at last, in a half-hearted way, consented, 
if Hogg would get 200 subscribers. However, as one of his friends of the "Forum," named Goldie, had set up as a bookseller, he showed his poem to him. Charmed with the poem, and ambitious to become a publisher, Goldie offered Hogg much better terms than Constable. After a little hesitation, Hogg agreed to hand over his poem to Goldie, by whom it was issued in the year 1813, and dedicated to the Princess Charlotte, a young lady of seventeen, in whom the hopes of the nation were centred. The "Queen's Wake" secured an instant popularity. Friends met the author on the street, and stopped to congratulate him; the reviews, with the sole exception of the "Eclectic," were commendatory. This may be regarded as Hogg's high watermark in poetic achievement; certainly he never attained at any later time as high a degree of popular recognition. The reason of this success is not far to seek. Here the Shepherd entered into his kingdom, the realm of faëry ; and, further, the relative shortness of each ballad did not betray his weakness in construction. The finest, by universal consent, is the ballad of "Bonnie Kilmeny." The soft, crooning music of the verse suits the twilight beauties of fairyland. Although it is so well known, we will quote some of the lines of the lovely tale :-

"Bonnie Kilmeny gaed up the glen;

But it wisna tae meet wi' Duneira's men,

Or the rosy monk of the isle to see,

For Kilmeny was pure as pure could be. 
But lang may her minny look ower the wa', An' lang may she seek in the greenwood shaw ;

Lang the Laird o' Duneira blame, An' lang, lang greet or Kilmeny come hame. Quhan mony a lang day had comit an' fled;

Quhan grief grew calm an' hope was dead ; Quhan mass for Kilmeny's soul had been sung; Quhan the bedesman had prayed an' the deid bell rung, Late, late in the gloamin', quhan a' was still ; Quhan the freenge was reid on the wastlin' hill, The wudde was sere, the mune i' the wane, The reek o' the cot hung ower the plain Like a little wee clud in the lift its lane ; Quhan the ingle lowed wi' an' eerie leme, Late, late in the gloamin' Kilmeny cam' hame. Kilmeny lukit up wi' a lovely grace, But nae smile was seen on Kilmeny's face, As still was her luke, an' as still was her e'e, As the stillness that lies on the emerant lea, Or the mist that sleeps on a waveless sea, But it seemed as the harp of the sky had rung, An' the airs of Heaven played round her tongue, Quhan she spak' o' the lovely forms she had seen In a land where sin had never been, A land of love and a land of licht, Withouten sun, or mune, or nicht."

Then there follows an account of the Land of Faëry ton long to quote. We are told how the fairies dealt with Kilmeny to fit her to become a denizen of that misty and mysterious realm. She had given her in vision what was coming on the earth-the fate of the luckless queen before whom her history was sung - the outburst of the French Revolution, and the terrible wars that 
followed, ending up with the final defeat of the eagle by the lion, when,-

"Wi' a mootit wing an' a waefu' maen

The eagle socht her eerie again.

But lang may she cour in her bluidy nest,

An' lang, lang sleik her oundit breast,

Afore she assay another flicht

Tae play wi' the norlan' Lion's micht."

It almost seems as if the poet had antedated his work, and we should read 1815 instead of 1813 in the dedication; but poets are seers.

"Then Kilmeny beggit again to see

The friends she had left in her ain countrie,

To tell of the place quhair she had been,

$A n^{\prime}$ the wonders that lay in the land unseen.

Wi' distant musik, soft and deep,

They lullit Kilmeny sound asleep ;

And quhan she waukint she lay her lane,

$A^{\prime}$ happit wi' floo'rs in the green wudde wain.

Quhan seven lang years had comit an' fled,

Quhan grief was calm and hope was dead,

Quhan scarce was remembered Kilmeny's name,

Late, late in the gloamin' Kilmeny cam' hame."

Next among the ballads, that make up the "Queen's Wake," in point of popularity, is "The Witch of Fife." Here there is the element of humour present, but it is introduced in a way that somewhat jars with the rest of the narrative. It would have maintained the artistic feeling of unity if there had been some preparation for this dive into farce. Even the fun should have been softened when the termination was to be the 
burning of the misguided old man as a "warlock." Sir Walter pointed out to Hogg the cruelty of the termination, so he added the last dozen stanzas that tell of the old man's escape. It might almost seem as if the Shepherd had been stopped somehow in the middle of his song, and a change come over his mood, ere he recommenced. Whether it was that the "sclate" on which he composed was full, and he had not at the time any convenience for engrossing his poem, or whether the first portion was written before a symposium in the Cowgrate with the "drouthy" Robertson and the "lean and dirty" printers, and the latter portion after, we know not. Any reader will observe that after the stanza-

“Awa', awa, ye ill woman, An ill daith met ye dee, Quhan ye have pruvit sae fause tae yer God Ye can never pruve trew tae me"-

the poem assumes a new complexion. Such a verse as that just quoted would naturally have been followed by summary vengeance being inflicted by the aggrieved and enraged husband on the recreant wife. Instead of that the old man goes to Carlisle with his wife to booze in the bishop's wine cellar. There are some stanzas in Hogg's best manner in the first portion of this ballad, as for instance-

“ An' quhan we cam tae the Lomond heicht, Sae lythly we lichted doon; And we drank fra the horns that never grew,

The beer that never was brewn. 
"Than up there rase a wee, wee man

Frae neath the moss grey stane;

His face was wan like the collifloure,

For he nouthir had bluid nor bane.

" He set a reed pipe tae his mouth,

An' he played sae bonnilye,

Till the grey curlew and the blackcock flew

Tae list tae his melodye.

"It rang sae sweet through the green Lomond,

That the nicht wind lowner blew ;

And it soopit alang the Loch Leven

An' waukint the white sea mew.

"It. rang sae sweet through the green Lomond,

Sae sweetly but an' sae shill,

That the weasels lap oot o' their mouldy holes

An' danced on the midnicht hill.

"The corby craw cam gledgin' near,

An' the ern gaed veering bye,

An' the trouts lap oot o' the Leven Loch

Charmed wi' the melody."

Some of the other ballads would be worthy of quotation did space permit. With perhaps less of mist and marvel about them, they have more of the condensation and self-restraint which characterise the best examples of the old ballad. Hogg was too garrulous, and versified too easily, to rival the grim suggestiveness of some of the models he set before him. There is, however, no one of the ballads of the "Queen's Wake" but will amply repay perusal. 
After two editions of the "Queen's Wake" had been quickly disposed of, the question of a third was mooted. Something of a commercial crisis occurred, and Hogg was informed that Goldie was too deeply involved to be able to keep afloat. This led him to think of offering the publishing of this third edition to Constable. However, when Goldie got word of this he bullied Hogg into withdrawing from his arrangement with Constable, and giving him the right to issue this new edition. It was not long printed till Goldie fulfilled the presages of the prophets of evil and became a bankrupt. This disaster had one good effect, it introduced our poet to Blackwood, who had only recently become a publisher. He took over and succeeded in disposing of the copies of the "Queen's Wake" still left in the hands of Goldie at a very considerable advantage to the author.

During the summer of the following year, Hogg, while the guest of Mr. Izett of Kinnaird, Athol, was urged by his hostess to illustrate his stay there by some poetical composition. The result of this was "Mador of the Moor," a poem founded on the view seen from the window of his room in Kinnaird House. Of course there are many beauties in the poem, but the story is too improbable. It is founded on the marriage of Robert II. with Elizabeth Mure, with whom by canonical law (but only by canonical law), his marriage was not permissable. In Hogg's hands it becomes an impossible story, in which minstrelsy and magic play their part in a way that sets probability at defiance. Another thing that hindered the success of 
"Mador" was the Spenserian stanza in which it was written. Hogg never seemed to catch the slow majestic melody of the Alexandrine with which the Spenserian stanza closes; and to this the Spenserian owes more than half its beauty. Yet, strange to say, Hogg could affirm: "There is no doubt whatever that my highest and most fortunate efforts in rhyme are contained in that poem."

His next literary venture was "The Pilgrims of the Sun." Through it he was involved in squabbles with various booksellers and printers, in which Constable, Miller, Murray, and Blackwood all figure, the last mainly as poet's friend. At length the poem did appear, but enjoyed only a very moderate amount of popularity. At the same time it received a number of highly favourable reviews; notably one from the "Eclectic," which had not been favourable to the "Queen's Wake."

A change, however, came over his fortunes from another quarter. The itch of farming came back upon him, and he applied to the Duke of Buccleuch for a small pendicle to another farm. He did not get exactly what he had craved, but he got a lease of the farm of Altrive for a rent so absolutely nominal that it never was so much as named. On this he erected a house somewhat better than the hut that already stood there; to this he removed his aged parents. Although Providence had marked out James Hogg for a poet, and though at times no one was more convinced of this than Hogg himself, he yet was perpetually pursued by the desire to be a store farmer; the dreams of his boyhood 
haunted his maturity. The farm of Mount Benger, adjoining Altrive, some years after his removal to Altrive, fell vacant, and Hogg was persuaded to become the tenant of it. The fact that the preceding tenants had failed and lost in it did not deter him. He thought, and was encouraged in the idea by his friends, that he could aid his sheep-farming by literature.

As we have to do with Hogg as a poet, not as a sheep-farmer, we shall not take up time relating his various commercial disasters. These disasters need not-seem strange when one remembers that Altrive was a hotel without the pay. He also made frequent and prolonged visits to Edinburgh. These absences did not conduce to his success in farming. But, further, he was ready to entertain liberally in the inn where he stayed. Although Hogg knew the points of a sheep as well as any man, he does not seem to have had business talent-the power of estimating chances and working out for profits.

$\mathrm{He}$ very soon found occasion to betake himself to literature; more money was needed to stock Mount Benger than he could easily furnish. He bethought him of his literary friends, and it occurred to him, if each of them would give him a poem, he might construct a miscellany, with considerable profit to himself, yet without much trouble. Some of his friends readily promised to do what he asked. Among these was Lord Byron, then at the height of his fame. He promised him "Lara," but forgot to perform; Hogg thinks, by advice. One whom he reverenced more than any 
other would afford him no assistance,-Sir Walter Scott declared, "Let every herrin' hang by its ain heid," and would have nothing to do with this scheme of the Shepherd's. Hogg was furiously enraged at this, and wrote to Scott in terms of unmeasured wrath, renouncing his friendship. He now changed his plan, and took up the idea of making it instead a series of parodies of the styles of the leading poets of the day, including, of course, himself. The whole was written within three weeks, and thereafter duly published, under the title of the "Poetic Mirror." In his parody of Scott there is not much venom, though a good deal of fun; but venom there is in his imitation of the poet Wordsworth. At the same time, Wordsworth at his weakest irresistibly suggests parody; the solemn insistence on the obvious, the profound conviction of the poet's own superiority, most manifest when he is most prosy, excites everyone with any sense of humour in him to poke fun at him-not that any one would deny the exceeding beauty of much that Wordsworth has written. The parody of his own style, in "The Gude Greye Katte," had it been written by any other, would have been most savage of all. Coleridge and Southey are not so well imitated. The inferiority of the "Poetic Mirror" to its contemporary the " Rejected Addresses" is undeniable.

We know that "to be wroth with one we love doth work like madness in the brain;" so it proved with the Shepherd in his wrath against his friend Sir Walter Scott. He got in tow with some wild fellows and 
formed a Bacchanalian Club. The principle of it seemed to be to be continuously drunk or getting drunk day in and day out. Hogg's habits had not fitted him for such orgies, and the result of this escapade was a serious illness. During this time of sickness, Sir Walter, unknown to the wayward child of genius, was watching over and caring for him. The discovery of this at once sent the impulsive Shepherd to the feet of Scott. I do not think anything in all Scott's history is fitted to give us a higher idea of his generosity than his treatment of Hogg at this time; whether we consider the request so unduly pressed, the abusive letter, or the orgie of drunkenness, Scott's conduct is above praise. Hogg's account of his friend's treatment redounds to his credit. $\mathrm{He}$ declares the quarrel to have been entirely on his side, and that he was wholly in the wrong.

Hogg now betook himself to drama, but without success. His genius was descriptive, not dramatic. About this time he began, but stuck for some time, "Queen Hynde." After an interval he completed it, and, having shown it to Sir Walter and had his high commendation, it was duly published. The versification has a striking resemblance to Scott's own, and proceeds in a smooth, equable flow; but the tale is one that somehow fails to interest. Perversely, Hogg proclaimed this as his finest poem; unfortunately, neither the reviews nor the public were of this opinion. An amusing description occurs in the "Autobiography" of a dinner given to Hogg by some admirers, where the chairman was unlucky enough to give voice to the 
common belief, persisted in to this day, that the "Queen's Wake" was the finest of their guest's works. At once Hogg flew into a rage, and declared vehemently his own preference for "Queen Hynde," offering to bet any money in support of his idea. Nobody took the bet. This was Hogg's last serious poem of any length.

In 1817 Hogg commenced "The Brownie of Bodsbeck," in imitation of the world-famous Waverley Novels. After lying for some time in MS., it had the misfortune to be published a little later than "Old Mortality," which it resembled so much in subject. It threatened to occasion a second quarrel with Sir Walter, who objected to the view Hogg presented of the Episcopalian party, and especially of Claverhouse. Although, thanks mainly to Andrew Lang, the controversy has not quite died down, no serious historian will now deny that there is greater truth in Hogg's view of Claverhouse than in Scott's. The want of constructive skill, the want, perhaps, rather of real effort after telling construction, is the defect most patent in this story; yet it is full of interest, if only for its characterization of types now disappeared, and its preservation of vanished traditions and superstitions. The plot turns on the efforts of some Covenanters in hiding near the farm of Chapelhope to get food without revealing their refuge among the hills. A curate had been murdered, and the notorious Claverhouse had been sent to ferret out the culprits, and, in the course of his investigations, commits many atrocities quite in accordance with the character assigned to him by tradition. The gudeman 
of Chapelhope is suspected of being a Covenanter, and treated with severity. However, as with all wellordered stories, everything comes right in the end. The character Hogg gives to John Graham of Claverhouse is in perfect accord with tradition, which is more than can be said for that presented to us by a greater in "Old Mortality." The most striking, and at the same time the best constructed, of Hogg's tales is "The Confessions of a Fanatic." High critical authority has declared against this being the unaided work of Hogg. Grounding on the fact that the writers of "Blackwood" had a free and easy way of attributing their own work to other people, Professor Saintsbury, in "Macmillan's Magazine," 1889, has decided that the story was over-written-curtailed and added toby Lockhart. Certainly the hatred of the Whigs had more of the scorpion sting of Lockhart than the easy tolerance of Hogg; further, there is not a little that suggests Lockhart's best novel, "Adam Blair," especially the mixture of sanctity and sin. Yet, on the other hand, the style is different-Lockhart was a purist in all matters of that sort. Near the beginning of the story, in what purports to be the preface, "The Editor's Narrative," we find reference to "an unguent hard to swallow." That is a statement Lockhart never would have perpetrated. Moreover, Hogg tacitly claimed it as his by publishing it among his collected tales. The free use of the supernatural is decidedly in Hogg's best manner. Professor Saintsbury's chief argument is that this story is singularly free of Hogg's 
worst faults. But this will prove Kilmeny also not to be authentic.

About this time Hogg began to busy himself with his "Jacobite Relics of Scotland." In search of these relics he trudged through a great portion of the Highlands of Scotland, interrogating all he met, and enquiring for songs and fragments of songs about Prince Charlie and his father. Sometimes his efforts were baffled by the suspicions of those at whom he made his enquiries. He was supposed to be an agent of the Government engaged in gathering proofs of complicity with the rebels. The first part of the "Relics" was published in 1819, and the second two years later. Hogg was by no means a purist; sometimes he admitted even manifest forgeries if they took his fancy, and again doctored such fragments as he picked up to suit some melody he knew, or his own ideas of poetic propriety.

Despite the failure of the Spy, Hogg had always had a hankering after the periodic press; so when Blackwood engaged his friend Pringle as editor of the newly started "Blackwood's," Hogg readily agreed to assist with occasional contributions. However, Pringle and Cleghorn, who was associated with him in the management of the magazine, differed from Blackwood, left him, and, helped by a rival publisher, started " The Edinburgh Monthly Magazine." Blackwood secured the services of two young men of brilliant talentLockhart, the son-in-law of Sir Walter Scott, and John Wilson, the redoubtable "Christopher North." In con- 
nection with the defection of Pringle and Cleghorn. Hogg wrote the so-called "Chaldee Manuscript." It is an account of Pringle and Cleghorn's desertion of Blackwood in language which suggests the Authorised Version of the Bible, the book of Daniel being specially imitated. This jeu d'esprit shocked some, amused more, but seriously irritated those connected with the "Edinburgh Monthly Magazine," the rival to that of Mr. Blackwood, or, to give him the name by which he was known among the young Parliament-house men, "Old Ebony." Hard-hitting as was the "Chaldee Manuscript" as it came from the pen of Hogg, it was made venomous by the additions to it by Lockhart and others. The result of this irritation was that it was withdrawn from a large number of the issue of "Blackwood" in which it appeared, and its place taken by another article. In consequence of this withdrawal of the "Chaldee Manuscript," it is a piece but little known, hence we shall give a few verses of it as a specimen.

"Chapter I. 1. And I saw in my dream and behold one like the messenger of a King came toward me from the east; and he took me up and carried me into the great city that looketh toward the north and toward the east, and ruleth over every people and kindred and tongue that handle the pen. 2. And he said unto me 'Take heed what thou seest for great things shall come of it-the moving of a straw shall be as a whirlwind, and the shaking of a reed as a great tempest.' 3. And I looked, and behold a man in plain apparel stood in the door of the house, and 
I saw his name and the number of his name; and his name was as it had been the colour of ebony, and his number that of a maiden when the days of the years of her virginity have expired. 4. And I turned mine eyes, and behold two beasts came from the land of the borders of the south, and when I saw them I wondered with great admiration. 7. And they said unto him, Give us of your wealth that we may eat and live and thou shalt enjoy the fruit of our labours for a time, times, and half a time. . . 16. Now in these days there lived a man who was crafty in counsel. . . 21. And he hated the book. . . 22. And he said unto the two beasts: ' Come ye and put your trust under the shadow of my wings, and we will destroy the man whose name is Ebony, and his book with him' . . 29. And the two beasts gave ear to him, and they came over unto him, and bowed down before him, with their faces to the earth."

It must be said that Pringle, to whom Hogg had shown the manuscript before it was printed, never became unfriendly to the Shepherd. At this point we must refer to the persistent caricature of Hogg that appeared in "Blackwood" under the heading of "Noctes Ambrosianæ." The Shepherd in them is at once coarser and more bibulous than the real man. Hogg, himself one of the most forgiving of men, was once so stung by some of the things put in his mouth that he consulted Sir Walter Scott as to what he should do to right himself. Sir Walter advised him to do nothing. Wilson, however, enraged Hogg 
beyond endurance by parodying "The Field of Waterloo," so our poet sent to Wilson a furious letter. "There was scarcely an abusive epithet in our language," says Hogg, "that I did not call him by." Wilson, however, laughed it off, and sent such a letter of apology as not only secured forgiveness from the easily placated Shepherd, but knit him closer to the culprit than before. Although he yielded to the advice of his friend Scott, Hogg felt sore at these travesties, not only for his own sake, but for the sake of others dearer to him than himself. Hogg had married in his fiftieth year, after a somewhat hidden courtship, lasting nearly ten years, Miss Margaret Phillips, the youngest daughter of an Annandale farmer in good position., Both socially and by education she was Hogg's superior, yet the marriage was one of singular happiness. To her dying day Mrs. Hogg could not hear of the "Noctes" representation of her late husband-and she survived him thirty-five years-without heightened colour and every sign of lively indignation. At the same time Wilson imagined the Shepherd of the "Noctes" to be a dramatisation of Hogg, standing much in the same relation to the real Hogg as-if the reader will pardon the comparison-the real Socrates stood to the interlocutor who bears his name in the Platonic Dialogues. It has therefore a certain historic value as showing Hogg as Wilson understood him.

Hogg's literary activity was largely occupied with writing prose tales, which were published in those delights of our grandmothers, the "Annuals." They 
were pretty books, well bound, and illustrated with steel engravings, the prettiness of which was obvious, and the contents were in harmony with the illustrations. The popularity of these compilations was at its height during the last decade of Hogg's life. He published also several collections of "Tales." As usual he was unfortunate in regard to his publishers. After long, and on the whole kindly, business intercourse with Blackwood, he quarrelled with him, and set off to London in search of better terms for the publication of his collected "Tales." He fell in with one Cochrane, who promised much; promises were the most that poor Hogg got from Cochrane. At the same time he became acquainted with a number of the brotherhood of the pen, whose society afforded him much pleasure if not much profit. In fact he was treated as a literary lion, and so was petted and feasted almost beyond his powers. The whole culminated in a feast in the Free Masons' Hall, on the anniversary of the birth of Robert Burns (and, according to his own mistaken idea, the anniversary of his own birth also). Sir John Malcolm, the most distinguished Borderer then living in London, was in the chair. Two sons of Burns were present. At this Hogg received what in newspaper phrase is called "a perfect ovation." What connection the audience, rising upon the entrance of one they desire to honour, cheering themselves hoarse and singing "For he's a jolly good fellow," has with the secondary Roman triumph, when only a sheep, not a bull, was sacrificed, it is difficult to see. Suffice it, Hogg was received with the 
honour due to one who rightfully claimed to be the legitimate successor to Burns as the songster-in-chief of Scotland. This honour was done to Hogg in the beginning of the year, the end of which saw Sir Walter in his grave.

The commercial disaster that some six years previously had befallen Scott, though it did not take the heart out of him, sapped his strength. Something like this happened to Hogg. He that had risen so easily and light-heartedly, and got over the failure of publishers, now seems to have lost heart in consequence of the bankruptcy of Cochrane. Nothing of note was published by him during the course of 1832 or 1833. Although he published nothing during both the years in question, he probably would be occupied with the composition of the two works - "The Domestic Manners and Private Life of Sir Walter Scott" and the "Life of Burns"-to which the present biographical sketch is an introduction. The "Life of Burns" was written in fulfilment of an engagement he and Motherwell, another Scottish poet, had entered into with Fullarton to edit the works of Burns, and precede it with a life of the poet. The opening chapter is taken up with a criticism of previous biographies of Burns; the next is occupied with a panegyric of the peasantry of Scotland. The third chapter, in which the life proper begins, is largely drawn from Burns's own autobiography. While there are few facts that are not the common property of all the biographers of Burns, there is a racy way of 
estimating these that is all Hogg's own-a peasant poet on a peasant poet. The selection of facts and incidents are fitted to bring out a side of Burns's character which harmonised most with that of Hogg himself. It is a very living Burns that is presented to us.

The other little work, here reprinted, "The Domestic Manners and Private Life of Sir Walter Scott," caused great wrath on the part of Lockhart, Scott's son-in-law and biographer. The truth is that Lockhart regarded himself as the high priest of the Scott cult, and, in consequence, the judge of the correct and orthodox way in which worship was to be offered to the immortal memory. Hogg, however, with as real an adoration for Scott, had known him from a different point of view. The only thing in the short booklet that might be called breach of taste is the passage about Lady Scott and her parentage. Altogether Lockhart's words about Hogg's death and these reminiscences- "It had been better for his fame had his end been of an earlier date, for he did not follow his best benefactor until he had insulted his dust" - were cruel and utterly unwarranted. Scott was not a plaster saint, and had a good many very human weaknesses. That Hogg, whom Lockhart despised, should presume to direct attention to these was not to be endured! No one reading "The Domestic Manners" will fail to rise from the perusal with a more loving appreciation of the sterling character of the great novelist, despite his weaknesses, than he had had before. It was issued in 1834 by Reid, a 
Glasgow publisher, as a thin $12 \mathrm{mo}$., preceded by a somewhat patronising biography of Hogg. It does not seem possible at this date to identify the writer of the life, but some things in it rather point to Motherwell, his coadjutor in editing the work of Burns, as the author of it.

The same year in which the little pamphlet on "The Domestic Manners of Sir Walter Scott" was published, Hogg sent out to the public his "Lay Sermons." These were intended not for the exposition of doctrine or the expression of religious feeling and inculcation of religious duty, but were devoted to duties on the lower plane, as their title intimates, of "Good Principles and Good Breeding." Although not exactly the kind of reading worthy Scotch folk of the religious type would betake themselves to of a Sunday, they were well fitted to be useful; had they been published nowadays the amusing anecdotes would not have been regarded as so much out of place. The late $\mathrm{Mr}$. Spurgeon, and still more, John M'Neill, have to a great extent broken down the barrier which custom had erected between laughter and Sunday sermons. At the time he was engaged in the composition of these "Sermons," he had another literary enterprise on hand. Cochrane, the London publisher, whose failure while he was in the Metropolis had been so sore a disappointment to Hogg, again approached him and induced Hogg to entrust to him the publication of a collection of stories called the "Montrose Tales." Again ill success followed both poet and publisher. 
After the work above mentioned was just ready for distribution to the booksellers, Cochrane failed. Not a few of his letters about this time are taken up with efforts to save something from the catastrophenegotiating for the 2000 copies of the "Montrose Tales" that were in Cochrane's premises, and so forth.

Although outwardly he kept his head erect, Hogg felt this last disaster keenly, and he was not now so young that he could hope for a much longer period of literary activity - he was on the confines of sixty-five. He still betook himself to hill and stream with rod and gun, but there was a loss of elasticity in step as well as spirit. In the autumn of 1835 he began to be somewhat out of sorts: jaundice supervened; still that was not thought much of; but the jaundice was really a symptom of something more serious. He gradually became worse, till, on the 21st of November, in close proximity to the real anniversary of his birth -66 years before-James Hogg fell asleep. His friends and his servants conveyed the body over the hills to the lonely churchyard of Ettrick, where he was buried within a stone's throw of the place where had stood the cottage in which he had been born.

Seventy years have passed since that bleak November day when all that was mortal of "The Ettrick Shepherd" was laid in the earth, and now we are beginning to be able to form a truer estimate of his real worth. Time works strange changes in the estimates of literary values. While they were all in life, Wilson, Lockhart, and Southey patronised the Shepherd; yet who reads 
the "Noctes Ambrosianæ" now, except students of the manners of the later Georgian days, and they find them coarse, and even at times dull? Nay, few read, luscious as it is, "The Isle of Palms." Who cares about Lockhart save as the biographer of Sir Walter Scott? And Southey, the poet laureate of the day, is as little read as the "Keepsakes," "Forget-Me-Nots," and "Amulets" of the period. Hogg, again, is still alive. Never is there a Scottish concert, unless it is restricted to the songs of Burns, but has in its programme some one or other of Hogg's lyrics, "When the Kye Comes Hame," or "Bonnie Prince Charlie." For reading, few lyrics can equal "Bird of the wilderness, blithesome and cumberless." Although so many beautiful poems have been written on the sky-lark, it may be doubted whether any other poet has to the same extent succeeded in expressing, in the melody of the words, the upward soaring of the lark, and his flood of music poured over the wide waste of grassy hills. Hogg's defects were largely the result of what may be called his fatal facility for rhyming; and what followed, as a natural consequence, an abhorrence of the labour of the file. His prose suffered from the same defects, only to a greater extent. If he sometimes, though but rarely, blotted out lines of verse, he never did so with regard to prose. What probably was a potent cause of defect was his inability to think out the plan of a story carefully, so that each part should have a due share in the working out of the plot. At the same time, his marvellous facility of invention kept the story going. Episodes are apt to 
put the main plot into the shade. The traditionary stories introduced into that pretty tale, "The Woolgatherer," do not help the progress of events, but rather hinder it, and, still more, withdraw the attention from the central idea. Still, after making all allowance for these and other defects, the Ettrick Shepherd's tales are wonderful. For pure fancy, for portrayal of Scottish character, he is equalled by few, and excelled by yet fewer. It speaks well for the taste of the present day that there is a revival of interest in the works of James Hogg.

In his early manhood, Hogg, with his athletic figure, his height of nearly six feet, his luminous blue eyes, and his long auburn locks that fell to his shoulders, was the cynosure of the eyes of all the maidens when of a Sunday he entered the parish church. In later years, while he lost much of this Adonis beauty, his was a comely, striking figure in the streets of the northern metropolis. His broad shoulders and capacious chest, his well turned legs and ankles, spoke health and activity. His face, which he declared to be out of all drawing, was lighted up with kindly good nature, and his blue eyes shone with that shrewd humour so often seen in the faces of the peasantry of Scotland, while the lofty white forehead removed the expression from the category of the commonplace. It will be long ere Scotland looks upon his like again. 


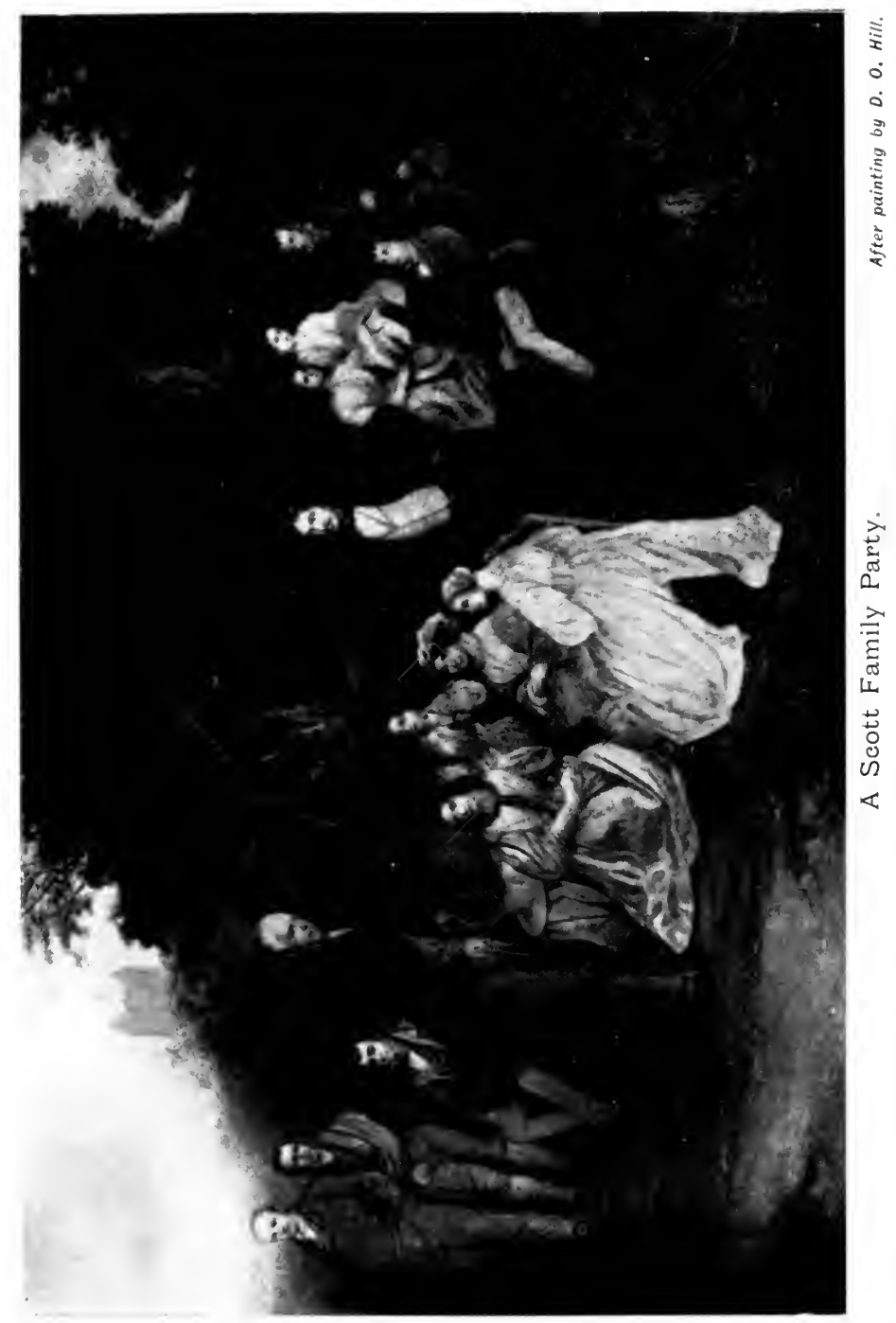




\section{DOMESTIC MANNERS OF SIR WALTER SCOTT.}

$\mathrm{N}$ the following miscellaneous narrative, $\mathrm{I}$ do not pretend to give a life of my illustrious and regretted friend. That has been done by half-adozen already, and will be given by his son-in-law fully and clearly - the only man who is thoroughly qualified for the task, and is in possession of the necessary documents. The whole that I presume to do is, after an intimate acquaintance of thirty years, to give a few simple and personal anecdotes, which no man can give but myself. It is well known what Sir Walter was in his study, but these are to show what he was in the parlour, in his family, and among his acquaintances; and, in giving them, I shall in nothing extenuate, or set down aught through partiality, and as for malice, that is out of the question.

The first time I ever saw Sir Walter was one fine day in the summer of 1801. I was busily engaged working in the field at Ettrick-house, when old Wat Shiel came posting over the water to me and told me that I boud to gang away down to the Ramsey-cleuch as fast as my 
feet could carry me, for there were some gentlemen there who wanted to see me directly.

"Wha can be at the Ramsey-cleuch that want to see me, Wat?"

"I couldna say, for it wasna me they spake to i' the bygangin', but I'm thinking it's the Shirra an' some o' his gang."

I was rejoiced to hear this, for I had seen the first volumes of "The Minstrelsy of the Border," and had copied a number of ballads from my mother's recital, or chaunt rather, and sent them to the editor preparatory to the publication of a third volume. I accordingly flung down my hoe and hasted away home to put on my Sunday clothes, but before reaching it I met the Shirra and Mr. William Laidlaw coming to visit me. They alighted, and remained in our cottage a considerable time, perhaps nearly two hours, and we were friends on the very first exchange of sentiments. It could not be otherwise, for Scott had no duplicity about him, he always said as he thought. My mother chaunted the ballad of Old Maitlan' to him, with which he was highly delighted, and asked her if she thought it ever had been in print? And her answer was, " $O$ na, na, sir, it never was printed i' the world, for my brothers an' me learned it an' many mae frae auld Andrew Moor, and he learned it frae auld Baubie Mettlin, wha was housekeeper to the first laird of Tushielaw. She was said to hae been another nor a gude ane, an' there are many queer stories about hersel', but $O$, she had been a grand singer o' auld songs an' ballads." 
"The first laird of Tushielaw, Margaret?" said he, "then that must be a very old story indeed?"

"Ay, it is that, sir! It is an auld story! But mair nor that, exceptin' George Warton an' James Stewart, there war never ane o' my sangs prentit till ye prentit them yoursel', an' ye hae spoilt them awthegither. They were made for singin' an' no for readin'; but ye hae broken the charm noo, an' they'll never sung mair. An' the worst thing of a', they're nouther richt spell'd nor richt setten down."

"Take ye that, Mr. Scott," said Laidlaw.

Scott answered with a hearty laugh, and the quotation of a stanza from Wordsworth, on which my mother gave him a hearty rap on the knee with her open hand and said, "Ye'll find, however, that it is a' true that I'm tellin' ye." My mother has been too true a prophetess, for from that day to this, these songs, which were the amusement of every winter evening, have never been sung more.

We were all to dine at Ramsey-cleuch with the Messrs. Brydon, but Scott and Laidlaw went away to look at some monuments in Ettrick churchyard, and some other old thing, I have forgot what, and I was to follow. On going into the stable-yard at Ramseycleuch I met with Mr. Scott's groom, a greater original than his master, at whom I asked if the Shirra was come?

"Oo ay, lad, the Shirra's come," said he. "Are ye the chap that mak's the auld ballads, an' sings them sae weel?" 
I said, I fancied it was I that he meant, though I could not say that I had ever made ony very auld ballads.

"Ay, then, lad, gang your ways into the house, and speir for the Shirra. They'll let, ye see where he is, an' he'll be very glad to see ye, that I'll assure you o.".

During the sociality of the evening, the discourse ran very much on the different breeds of sheep, that everlasting drawback on the community of Ettrick Forest. The original black-faced forest breed being always denominated the short sheep, and the Cheviot breed the long sheep. The disputes at that time ran very high about the practicable profits of each. Mr. Scott, who had come into that remote district to visit a bard of Nature's own making and preserve what little fragments remained of the country's legendary lore, felt himself rather bored with the everlasting question of the long and short sheep. So, at length, putting on his most serious calculating face, he turned to Mr. Walter Brydon, and said, "I am rather at a loss regarding the merits of this very important question. How long must a sheep actually measure to come under the denomination of a long sheep?"

Mr. Brydon, who, in the simplicity of his heart, neither perceived the quiz nor the reproof, fell to answer with great sincerity, "It's the woo', sir; it's the woo' that mak's the difference, the lang sheep hae the short woo' an' the short sheep hae the lang thing, an' these are just kind o' names we gie them, ye see."

Laidlaw got up a great guffaw, on which Scott could 
not preserve his face of strict calculation any longer; it went gradually awry, and a hearty laugh followed. When I saw the very same words, repeated near the beginning of the Black Dwarf, how could I be mistaken of the author? It is true that Johnnie Ballantyne swore me into a nominal acquiescence to the contrary for several years, but in my own mind I could never get the better of that and several other coincidences.

The next day we went off, five in number, to visit the wilds of Rankleburn, to see if, on the farms of Buccleuch and Mount Comyn, the original possession of the Scotts, there were any relics of antiquity which could mark out the original residence of the chiefs whose distinction it was to become the proprietors of the greater part of the border districts. We found no remains of either tower or fortalice, save an old chapel and churchyard, and the remnants of a mill-kiln and mill-dam, where corn never grew, but where, as old Satchells very appropriately says:

"Had heather bells been corn o' the best, The Buccleuch mill would have had a noble grist."

It must have been used for grinding the chief's black mails, which it is well known were all paid to him in kind; and an immense deal of vitual is still paid to him in the same way, the origin of which no man knows.

Besides having been mentioned by Satchells, the most fabulous historian that ever wrote, there was a remaining tradition in the country that there was a font-stone of blue marble, out of which the ancient heirs of 
Buccleuch were baptized, covered up among the ruins of the old church. Mr. Scott was curious to see if we could discover it, but on going among the ruins where the altar was known to have been, we found the rubbish at that spot dug out to the foundation, we knew not by whom, but it was manifest that the font had either been taken away, or that it had never been there. I never heard since that it had ever been discovered by any one.

As there appeared, however, to have been a sort of recess in the eastern gable, we fell a-turning over some loose stones, to see if the baptismal font was not there, when we came to one half of a small pot encrusted thick with rust. Mr. Scott's eyes brightened, and he swore it was part of an ancient consecrated helmet. Laidlaw, however, fell a picking and scratching with great patience until at last he came to a layer of pitch inside, and then, with a malicious sneer, he said, "The truth is, Mr. Scott, it's nouther mair nor less than an auld tarpot, that some of the farmers hae been buisting their sheep out o' $i$ ' the kirk lang syne." Sir Walter's shaggy eye-brows dipped deep over his eyes, and, suppressing a smile, he turned and strode away as fast as he could, saying, that "we had just rode all the way to see that there was nothing to be seen."

$\mathrm{He}$ was at that time a capital horseman, and was riding on a terribly high-spirited grey nag, which had the perilous fancy of leaping every drain, rivulet, and ditch that came in our way. The consequence was, that he was everlastingly bogging himself, while sometimes 
the rider kept his seat in spite of the animal's plunging, and at other times he was obliged to extricate himself the best way he could. In coming through a place called the Milsey Bog, I said to him, "Mr. Scott, that's the maddest de'il of a beast I ever saw. Can you no gar him tak' a wee mair time? he's just out o' ae lair intil another wi' ye."

"Ay," said he, "he and I have been very often like the Pechs (Picts) these two days past, we could stand straight up and tie the latchets of our shoes." I did not understand the allusion, nor do I yet, but those were his words.

We visited the old castles of Tushielaw and Thirlstane, dined and spent the afternoon and the night with Mr. Brydon of Crosslee. Sir Walter was all the while in the highest good humour, and seemed to enjoy the range of mountain solitude, which we traversed, exceedingly. Indeed, I never saw him otherwise in the fields. On the rugged mountains, and even toiling in the Tweed to the waist, I have seen his glee surpass that of all other men. His memory, or, perhaps I should say, his recollection, was so capacious, so minute, and sterling, that a description of what I have witnessed regarding it would not gain credit. When in Edinburgh, and even Abbotsford, I was often obliged to apply to him for references in my historical tales, that so I might relate nothing of noblemen and gentlemen named that was not strictly true. I never found him at fault. In that great library, he not only went uniformly straight to the book, but ere ever he stirred from the spot, turned up 
the page which contained the information I wanted. I saw a pleasant instance of this retentiveness of memory recorded lately of him, regarding Campbell's " Pleasures of Hope," but I think I can relate a more extraordinary one.

$\mathrm{He}$, and Skene of Rubislaw, and I were out one night about midnight, leistering kippers in Tweed," about the end of January, not long after the opening of the river for fishing, which was then on the tenth, and Scott having a great range of the river himself, we went up to the side of the Rough Haugh of Elibank; but when we came to kindle our light, behold our peat was gone out. This was a terrible disappointment, but to think of giving up our sport was out of the question, so we had no other shift save to send Rob Fletcher all the way through the darkness, the distance of two miles, for another fiery peat.

The night was mild, calm, and as dark as pitch, and while Fletcher was absent we three sat down on the brink of the river, on a little green sward which I never will forget, and Scott desired me to sing them my ballad of "Gilman's-cleuch." Now, be it remembered, that this ballad had never been printed, I had merely composed it by rote, and, on finishing it three years before, had sung it once over to Sir Walter. I began it, at his request, but at the eighth or ninth stanza I stuck in it, and could not get on with another verse, on which he

* Sir Walter alludes in the notes to his collected work by Cadell, to his "fire hunting" expeditions. Hogg enables us to fill up the outline of one of them. 
began it again and recited it every word from beginning to end. It being a very long ballad, consisting of eighty-eight stanzas, I testified my astonishment, knowing that he had never heard it but once, and even then did not appear to be paying particular attention. He said he had been out with a pleasure party as far as the opening of the Firth of Forth, and, to amuse the company, he had recited both that ballad and one of Southey's ("The Abbot of Aberbrothock)," both of which ballads he had only heard once from their respective authors, and he believed he recited them both without misplacing a word.

Rob Fletcher came at last, and old Mr. Laidlaw of the Peel with him, carrying a lantern, and into the river we plunged in a frail bark which had suffered some deadly damage in bringing up. We had a fine blazing light, and the salmon began to appear in plenty, "turning up sides like swine;"* but woe be to us, our boat began instantly to manifest a disposition to sink, and in a few minutes we reached Gleddie's Weal, the deepest pool in all that part of Tweed. When Scott saw the terror that his neighbour old Peel was in, he laughed till the tears blinded his eyes. Always the more mischief the better sport for him. "For God's sake, push her to the side!" roared Peel. "Oh, she goes fine," said Scott.

$$
\begin{aligned}
& \text { "An' gin the boat war bottomless, } \\
& \text { An' seven miles to row." }
\end{aligned}
$$

* Guy Mannering. 
A verse of an old song; and during the very time he was reciting these lines, down went the boat to the bottom, plunging us all into Tweed, over head and ears. It was no sport to me at all, for I had no change of raiment at Ashiesteel, but that was a glorious night for Scott, and the next day was no worse.

I remember leaving my own cottage here one morning with him, accompanied by my dear friend, William Laidlaw, and Sir Adam Ferguson, to visit the tremendous solitudes of Loch-Skene and the Grey-mare's-tail. I conducted them through that wild region by a path, which, if not rode by Clavers, as reported, never was rode by another gentleman. Sir Adam rode inadvertently into a gulf and got a sad fright, but Sir Walter, in the very worst paths, never dismounted, save at Loch-Skene to take some dinner. We went to Moffat that night, where we met with Lady Scott and Sophia, and such a day and night of glee I never witnessed. Our very perils were to him matter of infinite merriment; and then there was a short tempered boot-boy at the inn, who wanted to pick a quarrel with him for some of his sharp retorts, at which Scott laughed till the water ran over his cheeks.

I was disappointed in never seeing some incident in his subsequent works laid in a scene resembling the rugged solitude around Loch-Skene, for I never saw him survey any with so much attention. A single serious look at a scene generally filled his mind with it, and he seldom took another. But, here, he took the names of all the hills, their altitudes, and relative situations with 
regard to one another, and made me repeat all these several times. Such a scene may occur in some of his works which I have not seen, and I think it will, for he has rarely ever been known to interest himself either in a scene or a character, which did not appear afterwards in all its most striking peculiarities.

There are not above three people now living, who, I think, knew Sir Walter better, and who understood his character better than I did, and I once declared that if I outlived him, I should draw a mental and familiar portrait of him; the likeness of which to the original could not be disputed. In the meantime, this is only a reminiscence, in my own homely way, of an illustrious friend among the mountains. That revered friend is now gone, and the following pages are all that I deem myself at liberty to publish concerning him.

The enthusiasm with which he recited and spoke of our ancient ballads, during that first tour through the Forest, inspired me with a determination immediately to begin and imitate them, which I did, and soon grew tolerably good at it. . I dedicated "The Mountain Bard," to him:

Bless'd be his generous heart, for aye,

He told me where the relic lay,

Pointed my way with ready will,

Afar on Ettrick's wildest hill ;

Watch'd my first notes with curious eye,

And wonder'd at my minstrelsy:

He little ween'd a parent's tongue

Such strains had o'er my cradle sung. 
The only foible $I$ ever could discover in the character of Sir Walter, was a too strong leaning to the old aristocracy of the country. His devotion for titled rank was prodigious, and, in such an illustrious character, altogether out of place. It amounted almost to adoration, and, not to mention the numerous nobility whom I have met at his own house and in his company, I shall give a few instances of that sort of feeling in him to which I allude.

Although he, of course, acknowledged Buccleuch as the head and chief of the whole clan of Scott, yet he always acknowledged Harden as his immediate chieftain, and head of that powerful and numerous sept of the name, and Sir Walter was wont often to relate, how he, and his father before him, and his grandfather before that, always kept their Christmas with Harden in acknowledgment of their vassalage. This he used to tell with a degree of exultation, which I always thought must have been astounding to everyone who heard it; as if his illustrious name did not throw a blaze of glory on the house of Harden a hundred times more than that van of old border barbarians, however brave, could throw over him.

$\mathrm{He}$ was, likewise, descended from the chiefs of Haliburton and Rutherford, on the maternal side, and to the circumstances of his descent from these three houses he adverted so often, mingling the arms in his escutcheon, that to me, alas! who, to this day could never be brought to discover any distinction in ranks, save what was constituted by talents or moral worth, it appeared 
perfectly ludicrous, thinking, as no man could help thinking, of the halo which his genius shed over those families, while he only valued himself as a descendant of theirs.

I may mention one other instance, at which I was both pleased and mortified. We chanced to meet at a great festival at Bowhill, when Duke Charles was living and in good health. The company being very numerous, there were two tables set in the dining-room, one along and one across. They were nearly of the same length, but at the one along the middle of the room all the ladies were seated, mixed alternately with gentlemen, and at this table all were noble, save, if I remember aright, Sir Adam Ferguson, whose everlasting good humour insures him a passport into every company. But I, having had some chat with the ladies before dinner, and always rather a flattered pet with them, imagined they could not possibly live without me, and placed myself among them. But $I$ had a friend at the cross table, at the head of the room, who saw better. Sir Walter, who presided there, arose, and addressing the Lord of Buccleuch, requested of him, as a particular favour and obligation, that he would allow Mr. Hogg to come to his table, for that, in fact, he could not do without him; and, moreover, he added,

"If ye reave the Hoggs o' Fauldshope,

Ye harry Harden's gear."

I, of course, got permission, and retired to Sir Walter's table, when he placed me on the right hand of the 
gentleman on his right hand, who, of course, was Scott of Harden. And yet, notwithstanding the broad insinuation about the Hoggs of Fauldshope, I sat beside that esteemed gentleman the whole night, and all the while took him for an English clergyman! I knew there were some two or three clergymen of rank there, connected with the family, and I took Harden for one of them; and though I was mistaken, I still say, he ought to have been one. I was dumb-foundered next day when the Duke told me that my divine whom I thought so much of was Scott of Harden, for I would have liked so well to have talked with him about old matters, my forefathers having been vassals under that house, on the lands of Fauldshope, for more than two centuries, and were only obliged to change masters with the change of proprietors. It was doubtless owing to this connection that my father had instilled into my youthful mind so many traditions relating to the house of Harden, of which I have made considerable use.

But the anecdote which I intended to relate, before my ruling passion of egotism came across me, was this:When the dinner came to be served, Sir Walter refused to let a dish be set on our table,* which had not been first presented to the Duke and the nobility. "No,

* Sir Walter, practical, and with a strong grasp of real life in his poetry, was always endeavouring to live in a world of fiction. His Abbotsford, the dinner here narrated, and the reception of the King at Edinburgh were continuous efforts to transplant himself into another age-not unlike children playing Crusaders, Reavers, Robinson Crusoes, \&c. 
no!" said he. "This is literally a meeting of the Clan and its adherents, and we shall have one dinner in the feudal style, it may be but for once in our lives."

As soon as the Duke perceived this whim, he admitted of it, although I believe the dishes were merely set down and lifted again. In the meantime, the venison and beef stood on the side-board, which was free to all, so that we were all alike busy from the beginning. At the end of our libations, and before we parted, some time in the course of the morning, the Duke set his one foot on the table and the other on his chair, requesting us all to do the same, with which every man complied, and in that position he sang, "Johnnie Cope, are ye wauken yet?" while all joined in the chorus. Sir Walter set his weak foot on the table and kept his position steadily, apparently more firm than when he stood on the floor, joining in the chorus with his straightforward bass voice* with great glee, enjoying the whole scene exceedingly, as he did every scene of hilarity that I ever saw. But though a more social companion never was born, he never filled himself drunk. He took always his wine after dinner, and, at least for upwards of twenty years, a little gin toddy after supper, but he was uniformly moderate in eating and drinking. He liked a good breakfast, but often confessed that he never knew what a good breakfast was

* Which means, we suppose, a voice that never varied its notes ; no-

winding bout

Of linked sweetness long drawn out. 
till he came to my cottage, but he should never want it again, and he kept steadily to his resolution.

He was a most extraordinary being. How or when he composed his voluminous works, no man could tell. When in Edinburgh, he was bound to the Parliamenthouse all the forenoon. He never was denied to any living, neither lady nor gentleman, poor nor rich, and he never seemed discomposed when intruded on, but always good-humoured and kind. Many a time have I been sorry for him, for I have remained in his study, in Castle Street, in hopes to get a quiet word of him, and witnessed the admission of ten intruders, foreby myself. Noblemen, gentlemen, painters, poets, and players, all crowded to Sir Walter, not to mention booksellers and printers, who were never absent, but these spoke to him privately. When at Abbotsford, for a number of years his house was almost constantly filled with company, for there was a correspondence carried on, and always as one freight went away, another came. It was impossible not to be sorry for the time of such a man thus broken in upon. I felt it exceedingly, and once, when I went down by particular invitation to stay a fortnight, I had not the heart to stay any longer than three days, and that space was generally the length of my visits. But Sir Walter never was discomposed. He was ready, as soon as breakfast was over, to accompany his guests wherever they chose to go, to stroll in the wood, or take a drive up to Yarrow, or down to Melrose or Dryburgh, where his revered ashes now repose. He was never out of humour when well, but when ill he was very cross, he 
being subject to a bilious complaint of the most dreadful and severe nature, accompanied by pangs the most excruciating," and when under the influence of that malady it was not easy to speak to him, and I found it always the best plan to keep a due distance. But then his suffering had been most intense, for he told me one day, when he was sitting as yellow as a primrose, that roasted salt had been prescribed to lay on the pit of his stomach, which was applied, and the next day it was discovered that his breast was all in a blister, and the bosom of his shirt burnt to a izel, and yet he never felt it!

But to return to our feast at Bowhill, from which I have strangely wandered, although the best of the fun is yet to come. When the Duke retired to the drawing-room he deputed Sir Alexander Don, who sat next him, to his chair. We had long before been all at one table. Sir Alexander instantly requested a bumper out of champaigne glasses to the Duke's health, with all the honours. It was instantly complied with, and everyone drank it to the bottom. Don then proposed the following of so good an example as his Grace had set us, and accordingly we were all obliged to mount our chairs again, and setting one foot on the table, sing Johnnie Cope over again. Everyone at least attempted it, and

* This fact-which we do not recollect to have seen noticed before, accounts for some inequalities of temper we have heard laid to Sir Walter's charge-his uncourteous treatment of Lord Holland, \&c. Before blaming any one for such freaks, we ought always to inquire into the state of the stomach. 
Sir Alexander sang the song in most capital style. The Scotts, and the Elliotts, and some Taits, now began to fall with terrible thuds on the floor, but Sir Walter still kept his station as steady as a rock, and laughed immoderately. But this was too good fun to be given up. The Marquis of Queensberry, who was acting as croupier, said that such a loyal and social Border Clan could never separate without singing "God Save the King," and that though we had drunk to his health at the beginning, we behoved to do it again and join in the anthem. We were obliged to mount our chairs again, and, in the same ticklish position, sing the King's anthem. Down we went, one after another. Nay, they actually fell in heaps above each other. I fell off and took a prodigious run to one corner of the room, against which I fell, which created great merriment. There were not above six stood the test this time, out of from thirty to forty. Sir Walter did, and he took all the latter bumpers off to the brim. He had a good head more ways than one.

There was no man who ever testified more admiration, and even astonishment, than he did at my poetical productions, both songs and poems, and sometimes in very high terms before his most intimate friends. It was somewhat different with regard to my prose works, with which he uniformly found fault, and always with the disagreeable adjunction, "how good they might have been made with a little pains." When "The Three Perils of Man" was first put to the press, he requested to see the proof slips, Ballantyne having been telling him 
something about the work. They were sent to him on the instant, and on reading them, he sent expressly for me, as he wanted to see me and speak with me about my forthcoming work. We being both at that time residing in Edinburgh, I attended directly, and I think I remembered every word that passed. Indeed, so implicit was my dependence on his friendship, his good taste, and judgment, that I never forgot a sentence nor a word that he said to me about my own works, but treasured them up in my heart.

"Well, Mr. Hogg, I have read over your proofs with a ६reat deal of pleasure, and, I confess, with some little portion of dread. In the first place, the meeting of the two princesses at Castle Weiry is excellent. I have not seen any modern thing more truly dramatic. The characters are strongly marked, old Peter Chisholme's in particular. Ah! man, what you might have made of that with a little more refinement, care, and patience! But it is always the same with you, just hurrying on from one vagary to another, without consistency or proper arrangement."

"Dear Mr. Scott, a man canna do the thing that he canna do."

"Yes, but you can do it. Witness your poems, where the arrangements are all perfect and complete; but in your prose works, with the exception of a few short tales, you seem to write merely by random, without once considering what you are going to write about."

"You are not often wrong, Mr. Scott, and you were 
never righter in your life than you are now, for when I write the first line of a tale or novel, I know not what the second is to be, and it is the same way with every sentence throughout. When my tale is traditionary, the work is easy, as I then see my way before me, though the tradition be ever so short, but in all my prose works of imagination, knowing little of the world, I sail on without star or compass."

"I am sorry to say that this is too often apparent. But, in the next place, and it was on that account I sent for you, do you not think there is some little danger in making Sir Walter Scott, of Buccleuch, the hero of this wild extravagant tale?"

"The devil a bit."

"Well, I think differently. The present chief is your patron, your sincere friend, and your enthusiastic admirer. Would it not then be a subject of regret, not only to yourself and me, but to all Scotland, should you, by any rash adventure, forfeit the countenance and friendship of so good and so great a man?"

“'There's nae part o' that at a', Mr. Scott. The Sir Walter of my tale is a complete hero throughout, and is never made to do a thing, or say a thing, of which his descendant, our present chief, winna he proud."

"I am not quite sure of that. Do you not think you have made him a rather too selfish character?"

" $O$, ay, but ye ken they were a' a little gi'en that gate, else how could they hae gotten haud o' a' the South o' Scotland, naebody kens how."

Sir Walter then took to himself a hearty laugh, and 
then pronounced these very words. "Well, Hogg, you appear to me just now like a man dancing upon a rope or wire, at a great height; if he is successful and finishes his dance in safety, he has accomplished no great matter; but if he makes a slip, he gets a devil of a fall."

"Never say another word about it, Mr. Scott, I'm satisfied; the designation shall be changed throughout, before I either eat or sleep." And I kept my word.

I went, when in Edinburgh, at his particular request, two or three days every week to breakfast with him, as I was then always sure of an hour's conversation with him, before he went to the Parliament-house, and I often went for many days successively, as I soon found it was impossible to be in his company without gaining advantage. But there was one Sunday morning I found him in very bad humour indeed. He was sitting at his desk in his study at Castle Street, and when I went in he looked up to me with a visage as stern as that of a judge going to pronounce sentence on a malefactor, and at the same time, he neither rose nor saluted me, which was always his wont, and the first words that he addressed to me were these, "Mr. Hogg, I am very angry with you, I tell you it plainly, and I think I have a right to be so. I demand, sir, an explanation of a sentence in your Spy of yesterday."

Knowing perfectly well to what sentence he alluded, my peasant blood began to boil, and I found it rushing to my head and face most violently, as I judged myself by far the most aggrieved. "Then I must demand an 
explanation from you, Mr. Scott," said I, "Were you the author of the article alluded to in my paper, which places you at the head, and me at the tail, nay, as the very dregs of all the poets of Britain?"

"What right had you, sir, to suppose that I was the author of it?" said he in perfect rage.

"Nay, what right had you to suppose that you were the author of it, that you are taking it so keenly to yourself?" said I. "The truth is, that when I wrote the remarks, I neither knew nor cared who was the author of the article alluded to; but before the paper went to press, I believed it to have been Mr. Southey, for Johnnie Ballantyne told me so, and swore to it; but if the feather suits your cap, you are perfectly welcome to it."

"Very well, Hogg," said he, "that is spoken like a man, and like yourself; I am satisfied. I thought it was meant as personal to me in particular. But never mind. We are friends again us usual. Sit down and we will go to our breakfast together immediately, and it shall never more be mentioned between us."

Mr. Southey, long afterwards, told me that he was not the author of that article, and he believed it to have been written by Scott. If it was, it was rather too bad of him; but he never said it was not his. It was a review of modern literature in the "Edinburgh Annual Register." As some readers of these anecdotes may be curious to see the offensive passage in the $S p y$, I shall here extract it; that work being long ago extinct, and only occasionally mentioned by myself, as a parent will 
sometimes mention the name of a dear, unfortunate, lost child, who has been forgotten by all the world beside.

"The papers which have given the greatest personal offence are those of Mr. Shuffleton, which popular clamour obliged the editor reluctantly to discontinue. Of all the poets and poetesses whose works are there emblematically introduced, one gentleman alone stood the test, and his firmness was, even by himself, attributed to forgiveness. All the rest, male and female, tossed up their noses and pronounced the writer an ignorant and an incorrigible barbarian. The Spy hereby acknowledges himself the author of these papers, and adheres to the figurative character he has there given of the poetical works of these authors. He knows, that in a future edition, it is expected that they are all to be altered or obliterated. They never shall! Though the entreaties of respected friends prevailed on him to relinquish a topic which was his favourite one, what he has published, he has published, and no private consideration shall induce him to an act of such manifest servility as that of making a renunciation. Those who are so grossly ignorant as to suppose the figurative characteristics of the poetry, as having the smallest reference to the personal characters of the authors, are below reasoning with. And since it has of late become fashionable with some great poets to give an estimate of their great powers in periodical works of distinction, surely others have an equal right to give likewise their estimates of the works of such bards. It is truly amus- 
ing to see how artfully a gentleman is placed at the head of a school of poetry, and one who is, perhaps, his superior at the tail of it. How he can make himself to appear as the greatest genius that ever existed. With what address he can paint his failings as beauties, and depict his greatest excellencies as slight defects, finding fault only with those parts which every one must admire. The design is certainly an original, though not a very creditable one. Great authors cannot remain always concealed, let them be as cautious as they will; the smallest incident often assisting curiosity in the discovery."- $-S p y$ for August 24th, 1811.

This last sentence, supposing Sir Walter to have been the author, which I now suspect he was, certainly contained rather too broad and too insolent a charge to be passed over with impunity. When I wrote it, I believed he was, but had I continued to believe so, I would not have called on him the next morning after the publication of the paper. Luckily, before putting the paper to press, I waited on Mr. John Ballantyne, and asked him who was the author of that insolent paper in his "Annual Register," which placed me as the dregs of all the poets in Britain.

"O, the paper was sent to our office by Southey," said he, "you know he is editor and part proprietor of the work, and we never think of objecting to anything that he sends us. Neither my brother James nor I ever read the article until it was published, and we both thought it was a good one."

Now this was a story beside the truth, for I found 
out afterwards that Mr. James Ballantyne had read the paper from manuscript, in a library, long before its publication, where it was applauded in the highest terms. I, however, implicitly believed it, as I have done everybody all my life. At that period, the whole of the aristocracy and literature of our country were set against me, and determined to keep me down; $;$ nay, to crush me to a nonentity. Thanks be to God! I have lived to see the sentiments of my countrymen completely changed.

There was once more, and only once, that I found Sir Walter in the same querulous humour with me. It was the day after the publication of my "Brownie of Bodsbeck." I called on him after his return from the Parliament-house, on pretence of asking his advice about some very important affair, but, in fact, to hear his sentiments of my new work. His shaggy eye-brows were hanging very low down, a bad prelude, which I knew too well. "I have read through your new work, Mr. Hogg," said he, "and must tell you downright plainly, as I always do, that I like it very ill-very ill indeed."

"What for, Mr. Scott?"

"Because it is a false and unfair picture of the times and the existing characters, altogether an exaggerated and unfair picture!"

"I dinna ken, Mr. Scott. It is the picture I have been bred up in the belief o' sin' ever I was born, and I

* What a horrible conspiracy ! 
had it frae them whom I was most bound to honour and believe. An' mair nor that, there is not one single incident in the tale-not one-which I cannot prove from history to be literally and positively true. I was obliged sometimes to change the situations to make one part coalesce with another, but in no one instance have I related a story of a cruelty or a murder which is not literally true. An' that's a great deal mair than you can say for your tale o' 'Auld Mortality.'"

"You are overshooting the mark now, Mr. Hogg. I wish it were my tale. But it is not with regard to that, that I find fault with your tale at all, but merely because it is an unfair and partial picture of the age in which it is laid."

"No, I shouldna hae said it was your tale, for ye hae said to your best friends that it was not, an' there I was wrang. Ye may hinder a man to speak, but ye canna hinder him to think, an' I can speak at the thinking. But, whoever wrote 'Auld Mortality,' kenning what I ken, an' what ye ken, I wadna wonder at you being illpleased with my tale, if ye thought it written as a counterpoise to that, but ye ken weel it was written lang afore the other was heard of."

"Yes, I know that a part of it was in manuscript last year, but I suspect it has been greatly exaggerated since."

"As I am an honest man, sir, there has not been a line altered or added, that I remember of. The original copy was printed. Mr. Blackwood was the only man, beside yourself, who saw it. He read it 
painfully, which I now know you did not, and I appeal to him."

"Well, well. As to its running counter with 'Old Mortality;' I have nothing to say. Nothing in the world. I only tell you, that with the exception of Old Nanny, the crop-eared Covenanter, who is by far the best character you ever drew in your life, I dislike the tale exceedingly, and assure you it is a distorted, a prejudiced, and untrue picture of the Royal party."

"It's a devilish deal truer than yours though, and on that ground I make my appeal to my country."

And with that I rose, and was going off in a great huff.

"No, nc! stop!" cried he, "you are not to go, and leave me again in bad humour. You ought not to be offended with me for telling you my mind freely."

"Why, to be sure, it is the greatest folly in the world for me to be sae. But ane's beuks are like his bairns, he disna like to hear them spoken ill o', especially when he is conscious that they dinna deserve it."

Sir Walter then, after his customary short goodhumoured laugh, repeated a proverb about the Gordons, which was exceedingly apropos to my feelings at the time, but all that I can do I cannot remember it, though I generally remembered everything that he said of any import. He then added, "I wish you to take your dinner with me to-day. There will be nobody with us but James Ballantyne, who will read you something new, and I wanted to ask you particularly about something which has escaped me at this moment. Ay, it 
was this. Pray had you any tradition on which you founded that ridiculous story about the Hunt of Eildon?"

"Yes, I had," said I, " as far as the two white hounds are concerned, and of the one pulling the poisoned cup twice out of the king's hand when it was at his lips."

"That is very extraordinary," said he, "for the very first time I read it, it struck me I had heard something of the same nature before, but how or where I cannot comprehend. I think it must have been when I was on the nurse's knee, or lying in the cradle, yet I was sure I heard it. It is a very ridiculous story that, Mr. Hogg: the most ridiculous story I ever read. What a pity it is that you are not master of your own capabilities, for that tale might have been made a good one."

It was always the same on the publication of any of my prose works. When "The Three Perils of Man" appeared, he read me a long lecture on my extravagance in demonology, and assured me I had ruined one of the best tales in the world. It is manifest, however, that the tale had made no ordinary impression on him, as he subsequently copied the whole of the main plot into his tale of "Castle Dangerous."

Sir Walter's conversation was always amusing, always interesting; there was a conciseness, a candour, and judiciousness in it which never was equalled. His anecdotes were without end, and I am almost certain they were all made off-hand, for I never heard one of them either before or after. His were no Joe 
Miller's jokes. The only time ever his conversation was to me perfectly uninteresting, was with Mr. John Murray, of Albemarle Street, London. Their whole conversation was about noblemen, parliamenters, and literary men of all grades, none of which I had ever heard of or cared about; but every one of which Mr. Murray seemed to know, with all their characters, society, and propensities. This information Sir Walter seemed to drink in with as much zest as I did his whisky toddy, and this conversation was carried on for two days and two nights, with the exception of a few sleeping hours; and there I sat beside them, all the while, like a perfect stump: a sheep who never got in a word, not even a bleat. I wish I had the same opportunity again.

I first met with Sir Walter at my own cottage in the wilds of Ettrick Forest, as above narrated, and then I spent two days and two nights in his company. When we parted, he shook my hand most heartily, and invited me to his cottage on the banks of the North Esk, above Lasswade. "By all means come and see me," said he, "and I will there introduce you to my wife. She is a foreigner, as dark as a blackberry, and does not speak the broad Scots so well as you and me; of course, I don't expect you to admire her much, but I shall assure you of a hearty welcome."

I went and visited him the first time I had occasion to be in Edinburgh, expecting to see Mrs. Scott a kind of half black-a-moor, whom our sheriff had married for a great deal of money. I knew nothing about her, and 
had never heard of her, save from his own description; but the words, "as dark as a blackberry," had fixed her colour indelibly on my mind. Judge of my astonishment when I was introduced to one of the most beautiful and handsome creatures, as Mrs. Scott, whom I had ever seen in my life. A brunette, certainly, with raven hair and large black eyes, but in my estimation a perfect beauty. I found her quite affable, and she spoke English very well, save that she put always the $d$ for the $t h$, and left the aspiration of the $h$ out altogether. She called me all her life, Mr. Ogg. I understood perfectly well what she said, but for many years I could not make her understand what I said; she had frequently to ask an explanation from her husband, and I must say this of Lady Scott, though it was well known how jealous she was of the rank of Sir Walter's visitors, yet I was all my life received with the same kindness as if I had been a relation or one of the family, although one of his most homely daily associates. But there were many others, both poets and play-actors, whom she received with no very pleasant countenance. Jeffrey and his satellites she could not endure, and there was none whom she disliked more than Brougham, for what reason I do not know, but I have heard her misca' him terribly, as well as "dat body Jeffrey." It might be owing to some reasons which I did not know about. After the review of "Marmion" appeared, she never would speak to Jeffrey again, for, though not a lady who possessed great depth of penetration, she knew how to appreciate the great powers of her lord, from the begin- 
ning, and despised all those who ventured to depreciate them.

I have heard Sir Walter tell an anecdote of this review of "Marmion." As he and Jeffrey, Southey, Curwin, and some other body, I have forgotten who, were sailing on Derwent water, at Keswick, in Cumberland, one fine day, Mr. Jeffrey, to amuse the party, took from his pocket the manuscript of the review of "Marmion," and read it throughout. This, I think, was honest in Jeffrey, but the rest of the company were astonished at his insolence, and at some passages did not know where to look. When he had finished, he said, "Well, Scott, what think you of it? what shall be done about it?" "At all events, I have taken my resolution what to do," said Scott, "I'll just sink the boat." The review was a little modified after that.

But to return to Lady Scott, she is cradled in my remembrance, and ever shall be as a sweet, kind, and affectionate creature. When any of the cottagers or retainers about Abbotsford grew ill, they durst not tell her, as it generally made her worse than the sufferers, and I have heard of her groaning, and occasionally weeping for a whole day and a good part of the night,

* We have heard this story with a variation. Jeftrey, in his review of "Marmion," while praising the author's talents highly, introduced some censure. Going to sup with Scott, he, in the honesty of his heart, took the proof sheets of the review with him and read them aloud. Mr. Jeffrey's manner is unfortunate, and he was considerably Scott's junior. Scott and all his friends (his wife in particular) took the matter in high dudgeon. The review was not modified. 
for an old tailor who was dying, and leaving a small helpless family behind him. Her daughter Anne was very like her, in the contour and expression of her countenance. Who was Lady Scott originally? I really wish anybody would tell me, for surely somebody must know. There is a veil of mystery hung over that dear lady's birth and parentage, which I have been unable to see through or lift up; and there have been more lies told to me about it, and even published in all the papers of Britain, by those who ought to have known, than ever was told about those of any woman that ever was born. I have, however, a few cogent reasons for believing that the present Sir Walter's grandfather was a nobleman of very high rank.*

Like other young authors, Sir Walter was rather vain of his early productions, and liked to make them the subject of conversation. He recited "Glenfinlas" one day to me on horseback, long before its publication. He read me also, "The Lay of the Last Minstrel," from manuscript, at least he and William Erskine (Lord Kineder), and James Ballantyne, read it, canto about. He always preferred their readings to his own. Not so with me. I could always take both the poetry and the story along with me better from his reading than any. other body's whatsoever. Even with his deep-toned bass voice, and his Berwick burr, he was a far better

* This impression, strange to say, was encouraged by Sir Walter. Falconbridge was contended to be a king's bastard. The anxiety to be connected with nobility by a wife's illegitimacy is a step beyond this in aristocratical devotion. 
reader than he was sensible of." Everything that he read was like his discourse : it always made an impression. He likewise read me "Marmion" before it was published, but I think it was then in the press, for a part of it at least was read from proof slips and sheets with corrections on the margin. The "Marmion" manuscript was a great curiosity. I wonder what became of it. It was all written off-hand, in post letters, from Ashiesteel, Mainsforth, Rokeby, and London. The readings of "Marmion" began on his own part. I had newly gone to Edinburgh, and knew nothing about the work-had never heard of it. But the next morning after my arrival, on going to breakfast with him, he sought out a proof sheet, and read me his description of my beloved "St. Mary's Lake," in one of his introductions, I think to canto second, to ask my opinion as he said of his correctness, as he had never seen the scene but once. I said there never was anything more graphic written in this world; and I still adhere to the assertion, so it was no flattery; and I, being perfectly mad about poetry then, begged of him to let me hear the canto that followed that vivid description, expecting to hear something more about my native mountains. $\mathrm{He}$ was then, to humour me, obliged to begin at the beginning of the poem, and that day he read me the two first books.

That night my friends, Grieve and Morison, who were as great enthusiasts as myself, expressed themselves so 
bitterly at my advantage over them, that the next morning I took them both with me, and they heard him read the two middle cantos, which $I$ am sure neither of them will ever forget. When we came to the door, Morison said, "For God's sake, Hogg, don't ring."

"What for," said I.

"Because I know there will be something so terribly gruff about him, I dare not for my soul go in," said he.

"You never were so far mistaken in your life," said I, "Sir Walter's manner is just kindness personified," and rang the bell.

When "The Lady of the Lake" was mostly, or at least partly, in manuscript, he said to me one evening, "I am going to adventure a poem on the public quite different from my two last, perfectly different in its theme, style, and measure." On which he took the manuscript from his desk, and read me the course of "The Fiery Cross" and "The Battle of the Trosachs." I said, "I could not perceive any difference at all between the style of that and his former poems, save that, because it was quite new to me, I thought it rather better." He was not quite well pleased with the remark, and was just saying I would think differently when $I$ had time to pursue the whole poem, when Sir John Hope came in, and I heard no more.

After that, he never read anything more to me before publishing, save one ghost story. His fame became so firmly established that he cared not a fig for the opinions of his literary friends beforehand. But there was one forenoon he said to me in his study, "I have 
never durst venture upon a real ghost story, Mr. Hogg, but you have published some such thrilling ones of late, that I have been this very day employed in writing one. I assure you, 'it's no little that gars auld Donald pegh,' but yon Lewis stories of yours frightened me so much that I could not sleep, and now I have been trying my hand on one, and here it is." He read it; but it did not make a great impression on me, for I do not know, at this moment, not having his works by me, where it is published. It was about the ghost of a lady, and, I think, appeared in the "Abbot" or "Monastery." He read me also a humorous poem in manuscript, which has never been published that I know of. It was something about finding out the happiest man, and making him a present of a new holland shirt.* Paddy got it, who had never known the good of a shirt. Mr. Scott asked me what I thought of it. I said the characters of the various nations were exquisitely hit off, but I thought the winding up was not so effective as it might have been made. He said he believed I was perfectly right. I never heard what became of that poem, or whether it was ever published or not, for living in the wilderness, as I have done, for the last twenty years, I know very little of what is going on in the literary world. One of Sir Walter's representatives has taken

"It appeared in the "Sale Room," a fourpenny literary weekly, published by John Ballantyne. It is a circumstance not generally known, that a communication to this publication, signed Christopher Corduroy, was the first thing that attracted Scott's notice to Lockhart, of whom he previously knew nothing. 
it upon him to assert that Sir Walter always held me in the lowest contempt! He never was farther wrong in his life, but Sir Walter would still have been farther wrong if he had done so. Of that, posterity will judge; but $I$ assure that individual that there never was a gentleman in the world who paid more respect or attention to a friend, than Sir Walter did to me, for the space of the thirty years that we were acquainted. True, he sometimes found fault with me, but in that there was more kindness than all the rest.

I must confess that, before people of high rank, he did not much encourage my speeches and stories. $\mathrm{He}$ did not then hang down his brows, as when he was illpleased with me, but he raised them up and glowered, and put his upper lip far over the under one, seeming to be always terrified at what was to come out next, and then he generally cut me short, by some droll anecdote, to the same purport of what I was saying. In this he did not give me fair justice, for, in my own broad homely way, I am a very good speaker, and teller of a story too.

Mrs. Hogg was a favourite of his. He always paid the greatest deference and attention to her. When we were married, I, of course, took her down to Abbotsford; and introduced her, and though the company was numerous, he did her the honour of leading her into the dining-room and placing her by his side. When the ladies retired, he, before all our mutual friends present, testified himself highly pleased with my choice, and added, that he wondered how I had the good sense and 
prudence to make such a one. "I dinna thank ye at a' for the compliment, Sir Walter," said I.

As for her, poor woman, she perfectly adored him. There was one day, when he was dining with us at Mount Benger, on going away, he snatched up my little daughter, Margaret Laidlaw, and kissed her, and then laying his hand on her head, said, "God Almighty bless you, my dear child!" on which my wife burst into tears. On my coming back from seeing him into the carriage, that stood at the base of the hill, I said, "What ailed you, Margaret?"

"O," said she, "I thought if he had but just done the same to them all, I do not know what in the world I would not have given!"

There was another year previous to that, when he was dining with me at the same place, he took a great deal of notice of my only son, James, trying to find out what was in him, by a number of simple questions, not one of which James would answer. He then asked me anent the boy's capabilities. I said he was a very amiable and affectionate boy, but I was afraid he would never be the Cooper of Fogo, for he seemed to be blest with a very thick head. "Why, but, Mr. Hogg, you know it is not fair to lay the saddle upon a foal," said he, "I, for my part, never liked precocity of genius all my life, and can venture to predict that James will yet turn out an honour to you and all your kin." I was gratified by the prediction, and lost not a word of it.

The boy had at that time taken a particular passion for knives, particularly for large ones, and to amuse him 
Sir Walter showed him a very large gardener's knife which he had in his pocket, which contained a saw, but I never regarded it, and would not have known it the next day. James, however, never forgot it, and never has to this day, and I should like very well, if that knife is still to be found, that James should have it as a keepsake of his father's warmest and most esteemed friend. Col. Ferguson, perceiving the boy's ruling passion, made him a present of a handsome, two-bladed knife. But that made no impression on James. Col. Ferguson he forgot the next day, but Sir Walter he never forgot till he came back again, always denominating him, "The man wi' the gude knife."

The last time Margaret saw him was at his own house in Maitland Street, a very short time before he finally left it. We were passing from Charlotte Square to make a call in Laurieston, when I said, "see, yon is Sir Walter's house, at yon red lamp." "O let me go in and see him once more?" said she.

"No, no, Margaret," said I, "you know how little time we have, and it would be too bad to intrude on his hours of quiet and study at this time of the day." " $O$, but I must go in," said she, "and get a shake of his kind, honest hand once more. I cannot go by." So I, knowing that

"Nought's to be won at woman's hand

Unless ye gie her a' the plea,"

was obliged to comply. In we went, and were received with all the affection of old friends, but his whole dis- 
course was addressed to my wife, while I was left to shift for myself among books and newspapers. $\mathrm{He}$ talked to her of our family, and of our prospects of being able to give them a good education, which he recommended at every risk, and at every sacrifice. $\mathrm{He}$ talked to her of his own family one by one, and of Mr. Lockhart's family, giving her a melancholy account of little Hugh John Lockhart (the celebrated Hugh Littlejohn), who was a great favourite of his, but whom, as he said that day, he despaired of ever seeing reach manhood.

The only exchange of words I got with him during that short visit, which did not extend to the space of an hour, was of a very important nature indeed. In order to attract his attention from my wife to one who, I thought, as well deserved it, I went close up to him with a scrutinizing look, and said, "Gudeness guide us, Sir Walter, but ye hae gotten a braw gown!" On which he laughed, and said, "I got it made for me in Paris (such a year), when certain great personages chose to call on me of a morning, and I never thought of putting it on since, until the day before yesterday, on finding that my every-day one had been sent to Abbotsford. But I shall always think the more highly of my braw gown, Mr. Hogg, for your notice of it." I think it was made of black twilled satin and lined.

But to return to some general anecdotes, with which I could fill volumes. When I first projected my literary paper the Spy, I went and consulted him, as I generally did in everything regarding literature. He shook his 
head, and let fall his heavy eyebrows, but said nothing. The upper lip came particularly far down. I did not like these prognostics at all; so I was obliged to broach the subject again, without having received one word in answer.

"Do you not think it rather dangerous ground to take after Addison, Johnson, and Henry M'Kenzie?" said he.

"No a bit!" said I, "I'm no the least feard for that. My papers may not be sae yelegant as theirs, but I expect to make them mair original."

"Yes, they will certainly be original enough, with a vengeance!" said he.

I asked him if he thought threepence would be a remunerating price? He answered, with very heavy brows, that, "taking the extent of the sale into proper calculation, he suspected she must be a fourpenny cut." He said this with a sneer which I could never forget. I asked him if he would lend me his assistance in it? He said he would first see how I came on, and if he saw the least prospect of my success, he would support me, and with this answer I was obliged to be content. $\mathrm{He}$ only sent me one letter for the work, enclosing two poems of Leyden's. He was, however, right in discouraging it, and I was wrong in adventuring it. I never knew him wrong in any of his calculations or inhibitions but once, and then I am sure my countrymen will join with me in saying that he was wrong. He wrote to me once when I was living in Nithsdale, informing me that he was going to purchase the estate of Broadmeadows, 
on Yarrow; that he was the highest offerer and was, he believed, sure of getting it; and that he had offered a half more on my account that I might be his chief shepherd and manager of all his rural affairs. The plan misgave. Mr. Boyd overbid him and became the purchaser, on which Sir Walter was so vexed, on my account, I having kept myself out of a place, depending upon his, and he actually engaged me to Lord Porchester as his chief shepherd, where I was to have a handsome house, a good horse, a small pendicle, rent free, and twenty pounds a year. I approved of the conditions as more than I expected or was entitled to, only they were given with this proviso, that "I was to put my poetical talent under lock and key for ever!" I have the letter. Does anybody think Sir Walter was right there? I can't believe it, and I am sure my friend, the present Lord Porchester, would have been the last man to have exacted such a stipulation. I spurned the terms, and refused to implement the bargain. This is the circumstance alluded to in the "Queen's Wake," as a reflection on Walter the Abbot, which I think it proper to copy here, to save researches for an extract where it may be impossible to find it. It alludes to the magic harp of Ettrick banks and Yarrow braes.

\footnotetext{
"The day arrived-blest be the day, Walter the Abbot came that wayThe sacred relic met his view :

Ah! well the pledge of heaven he knew; He screw'd the chords, he tried a strain, 'Twas wild-he tuned and tried again.
} 
Then pour'd the numbers, bold and free, The ancient magic melody.

The land was charm'd to list his lays,

It knew the harp of ancient days.

The Border Chiefs, that long had been

In sepulchres, unhearsed and green,

Pass'd from their mouldy vaults away

In armour red and stern array;

And by their moonlit halls were seen,

In vizor, helm, and habergeon.

Even fairies sought our land again,

So powerful was the magic strain.

Blest be his generous heart for aye,

He told me where the relic lay,

Pointed my way with ready will

Afar on Ettrick's wildest hill ;

Watch'd my first notes with curious eye,

And wondered at my minstrelsy.

He little weened a parent's tongue

Such strains had o'er my cradle sung!

$O$, could the bard I loved so long

Reprove my fond aspiring song?

Or could his tongue of candour say

That I should throw my harp away:

Just when her notes began with skill

To sound beneath the Southern hill,

And twine around my bosom's core?

How could we part for evermore?

'Twas kindness all,-I cannot blame,

For bootless is the minstrel flame.

But sure a bard might well have known

Another's feelings by his own!"

QUEEN'S WAKe. 6th edit. p. 336-7.

I never knew any gentleman so shy and chary of his 
name and interest as Sir Walter was, and though I know Allan Cunningham and Captain J. G. Burns will not join me in this, "Let every man roose the ford as he finds it." He never would do anything for me in that, save by the honour of his undeviating friendship and genuine good advices, both of which were of great value to me, insuring me a welcome among all the genteel company of the kingdom, and the other tending greatly to guide my path in a sphere with which I was entirely unacquainted, and these I set a high value on. But he would never bring me forward in any way by the shortest literary remark in any periodical-never would review any of my works, although he once promised to do it. No, he did not promise; he only said before several friends, to whom he had been speaking very highly of the work, that he was thinking of doing it. But seeing, I suppose, that the poem did not take so well as he had anticipated, he never accomplished his kind intent. I asked him the following year why he had not fulfilled his promise to me.

"Why, the truth is, Hogg," said he, "that I began the thing, and took a number of notes, marking extracts, but I found that to give a proper view of your poetical progress and character, I was under the necessity of beginning with the ballads and following through 'The Wake' and all the rest, and, upon the whole, I felt that we were so much of the same school, that, if I had said of you as I wished to say, I would have been thought by the world to be applauding myself."

I cannot aver that these were Sir Walter's very 
words, but they were precisely to that purport. But I, like other disappointed men, not being by half satisfied with the answer, said, "Dear Sir Walter, ye can never suppose that I belang to your school of chivalry! Ye are the king o' that school, but I'm the king $o^{\prime}$ the mountain and fairy school, which is a far higher ane nor yours."

He rather hung down his brows, and said, "The higher the attempt to ascend, the greater might be the fall;" and changed the subject, by quoting the saying of some old English baronet in a fox chase.

$\mathrm{He}$ paid two high compliments to me, without knowing of either, and although some other person should have related these rather than me, I cannot refrain from it. One of them was derogatory to himself too, a thing which a young poet is not very apt to publish. He was, he said, quarter-master to the Edinburgh gentlemen cavalry, and composed a song for the corps, got a friend to learn it and sing it at the mess, but it did not take very well. At length a Mr. Robertson got up and said, "Come, come, that's but a drool of a song. Let us have Donald M'Donald." On which Donald M'Donald was struck up, and was joined in with such glee that all the mess got up, joined hands, and danced round the table, and, added Scott, "I joined the ring too and danced as well as I could, and there were four chaps, all of the clan Donachie, who got so elevated that they got upon the top of the table and danced a Highland reel to the song." He did not know it was mine until after he had told the anecdote, when 
I said, "Dear man, that sang's mine, and was written sax or seven years bygane. I wonder ye didna ken that."

There was another day, as we were walking round the north side of St. Andrew's Square, to call on Sir C. Sharpe in York Place, he said to me, laughing very heartily, "I found Ballantyne in a fine quandary yesterday, as I called on leaving the Parliament-house. He was standing behind his desk, actually staring, and his mouth quite open. 'I am glad you have come in, Mr. Scott,' said he, 'to tell me if you think I am in my right senses to-day, or that $I$ am in a dream?' ' $O$, it is quite manifest, from the question, that you are not in your right senses!' said I, ' what is the matter?' 'Here is a poem sent me by Mr. Gillies, to publish in a work of his,' said he ; 'it is in his own handwriting, and the gradation of the ascent is so regular and well-managed, that I am bound to believe it is his. Well, before you came in, I read and read on, in these two proofs, until at last I said to myself, Good Lord, is this the poetry of Mr. Gillies that $I$ am reading? I must be asleep, and dreaming. And then I bit my little finger, to prove if I was not asleep, and I thought I was not. But sit down and judge for yourself.'"

"So James read the poem to me from beginning to end," continued he, "and then said, "Now, what think you of this ?' 'The only thing that I can say,' said I, 'is, that the former part of the poem is very like the writing of an eunuch, and the latter part like that of a man. The style is altogether unknown to me, but $\mathrm{Mr}$. 
Gillies's it cannot be." ' I was sorry I durst not inform him it was mine, for it had been previously agreed between Mr. Gillies and me that no one should know. It was a blank verse poem, but I have entirely forgotten what it was about; the latter half only was mine.

"'So you say that the poetry is not the composition of Mr. Gillies?' said James.

"' Yes, I do, positively. The thing is impossible.'

" 'Well, sir, I can take your word for that; and I have not lost my senses, nor am I dreaming at all."

There was one day that I met with him on the North Bridge, on his return from the Court of Session, when he took my arm, and said, "Come along with me, Hogg, I want to introduce you to a real brownie, one who does a great deal of work for me, for which I am paid rather liberally." I accompanied him into one of the register offices, where a good-looking, little, spruce fellow, his deputy clerk, I suppose, produced papers, bunch after bunch, to the amount of some hundreds, all of which he signed with W. Scott, laughing and chatting with me all the while.* We then took a walk round the Calton Hill, till dinner time, when I went home with him and met Ballantyne and Terry. I think it was on that day, for it was during a walk round the Calton Hill, and I never enjoyed that pleasure with him but twice in my life, that we were discussing the merits of his several poems. "The Lady of the Lake" had an

*We recommend this to the special notice of Mr. Wallace of Kelly. 
unprecedented run previous to that, and as it was really my favourite, I was extolling it highly, assured that I was going on safe ground, but I found that he preferred "Marmion," and said something to the following effect: that "The Lady of the Lake" would always be the favourite with ladies and people who read merely for amusement, but that "Marmion" would have the preference by real judges of poetry. I have heard people of the first discernment express the same opinion since. For me, I think in "The Lady of the Lake" he reached his acme in poetry; for, in fact, the whole, both of his poetry and prose, have always appeared to me as two splendid arches, of which "The Lady of the Lake" is the key-stone of one, and "Guy Mannering" and "Old Mortality" the joint key-stones of the other. I should like very well to write a review of his whole works, but that is quite out of my way at present.

The only other walk that I ever got with him round the Calton Hill was several years subsequent to that. At that time I did not believe that he was the author of the celebrated novels, for Johnnie Ballantyne had fairly sworn me out of my original fixed belief, so I began about them very freely, and he did the same, laughing heartily at some of the jokes, and often standing still and sitting down and telling me where he thought the author had succeeded best and where least, and there were some places where he did not scruple to say he had failed altogether. He never tried to defend any passage when it was attacked, but generally laughed at the remarks. 
There cannot be a better trait of Sir Walter's character than this, that all who knew him intimately loved him; nay, many of them almost worshipped him. The affection and subservience of the two Messrs. Ballantyne far surpassed description. They were entrusted with all his secrets, and all his transactions, and faithful to the last, and I know, that had he taken some most serious advices which James gave him, he never would have been involved as he was. In James he always reposed the most implicit confidence. John he likewise trusted with everything, and loved him as a wayward brother, but he often broke a joke at his expense. There was one day I was telling the Sheriff some great secret about the author of a certain work or article, I have quite forgot what it was, when he said, "I suspect you are widely misinformed there, Mr. Hogg, for I think I know the author to be a very different person."

"Na, na, Mr. Scott, you are clean wrang," said I, "for Johnnie Ballantyne tauld me, an' he couldna but ken."

"Ay, but ye should hae ascertained whether it was leeing Johnnie or true Johnnie who told you that, before you avouched it; for they are two as different persons as exist on the face of the earth," said he, "Had James. told you so, you might have averred it, for James never diverges from the rightforward truth." As Mr. Southey once told me the very same thing, I think I am at liberty to publish the sentiments of two such eminent men of the amiable deceased. James was a man of pomp and circumstance, but he had a good affectionate 
heart. It was too good and too kind for this world, and the loss, first of his lady, and then of his great patron and friend, broke it, and he followed him instantly to the land of forgetfulness. How strange it is that all connected with those celebrated novels have been hunted off the stage of time as it were together! The publisher, the author, the two printers, and, last of all, the corrector of the press, the honest and indefatigable Daniel M'Corkingdale,-all gone! and none to tell the secrets of that faithful and devoted little community.

There was no man knew Scott so well as James Ballantyne, and I certainly never knew a man admire and revere a friend and patron so much. If any person ventured to compare other modern productions with those of Scott, he stared with astonishment, and took it as a personal insult to himself. There was one time that, in my usual rash, forward way, I said that Miss Ferrier's novels were better than Sir Walter's. James drew himself up-I wish any reader of this had seen his looks of utter astonishment, for he was always a sort of actor, James-"What do I hear? what do I hear?" cried he, with prodigious emphasis, "is it possible that I hear, sir, such a sentiment drop from your lips?" I was obliged to burst out a-laughing and run away.

Sir Walter's attached and devoted friends were without number, but William Erskine and James Ballantyne were his constant and daily associates. It is a pity that Ballantyne had not left a written character of him, for he could and would have done him justice. But the interesting part of their correspondence will soon all 
come to light in Lockhart's life of his illustrious fatherin-law. He was the only one I ever knew whom no man, either poor or rich, held at ill-will. I was the only exception myself, that ever came to my knowledge, but that was only for a short season, and all the while it never lessened his interest in my welfare. I found that he went uniformly on one system. If he could do good to any one, he would do it, but he would do harm to no man. He never resented a literary attack, however virulent, of which there were some at first, but always laughed at them. This showed a superiority of mind and greatness of soul which no other young author is capable of. He never retaliated, but trusted to his genius to overcome all; and it was not on a bruised reed that he leaned.

Although so shy of his name and literary assistance, which, indeed, he would not grant to any one, on any account, save to Lockhart, yet to poor men of literary merit his purse-strings were always open, as far as it was in his power to assist them. I actually knew several unsuccessful authors who for years depended on his bounty for their daily bread. And then there was a delicacy in his way of doing it, which was quite admirable. He gave them some old papers or old ballads to copy for him, pretending to be greatly interested in them, for which he sent them a supply every week, making them believe that they were reaping the genuine fruit of their own labours.

There was one day, when I was chatting with Ballantyne in his office, where I was generally a daily visitor, 
as well as my illustrious friend, I chanced to say that I never in my life knew a man like Scott; for that I knew to a certainty he was at that time, feeling himself a successful author, lending pecuniary assistance to very many unsuccessful ones, and the best thing of all, he never let his left hand know what his right hand was doing.

Ballantyne's face glowed with delight, and the tear stood in his eye, "You never were more right in your life," said he, "you never were more right in your life! and I am glad that you know and so duly appreciate the merits of our noble, our invaluable friend. Look here," and with that he turned up his day-book, and added, "some word it seems had reached Scott that Maturin, the Irish poet, was lying in prison for a small debt, and here have I, by Mr. Scott's orders, been obliged to transmit him a bill of exchange for sixty pounds, and Maturin is never to know from whom or whence it came." I have said it oft, and now say it again for the last time, that those who knew Scott only from the few hundreds, or, I might say hundreds of thousands of volumes to which he has given birth and circulation through the world, knew only one-half of the man, and that not the best half either. As a friend, he was sometimes stern, but always candid and sincere, and I always found his counsels of the highest value, if I could have followed them. I was indebted to him for the most happy and splendid piece of humorous ballad poetry which I ever wrote. $\mathrm{He}$ said to me one day after dinner, "It was but very lately, Mr. Hogg, 
that I was drawn by our friend, Kirkpatrick Sharpe, to note the merits of your ballad, 'The Witch of Fife.' There never was such a thing written for genuine and ludicrous humour, but why in the name of wonder did you suffer the gude auld man to be burnt skin and bone by the English at Carlisle? (for, in the first and second editions, that was the issue). I never saw a piece of such bad taste in all my life. What had the poor old carl done to deserve such a fate? Only taken a drappy o' drink too much, at another man's expense; which you and $I$ have done often. It is a finale which $I$ cannot bear, and you must bring off the old man, by some means or other, no matter how extravagant or ridiculous in such a ballad as yours; but by all means bring off the fine old fellow, for the present termination of the ballad is one which I cannot brook." I went home, and certainly brought off the old man with flying colours, which is by far the best part of the ballad. I never adopted a suggestion of his, either in prose or verse, which did not improve the subject. He knew mankind well. He knew the way to the human heart, and he certainly had the art of leading the taste of an empire, I may say, of a world, above all men that ever existed. As long as Sir Walter Scott wrote poetry, there was. neither man nor woman ever thought of either reading or writing anything but poetry; but the instant that he gave over writing poetry, there was neither man nor woman ever read it more! All turned to tales and novels, which I, among others, was reluctantly obliged to do. Yes, I was obliged, from the tide, the irre- 
sistible current that followed him, to forego the talent which God had given me at my birth, and enter into a new sphere with which I had no acquaintance. The world of imagination had been opened wide to me, but the world of real life I knew nothing of. Sir Walter knew it, in all its shade and gradations, and could appreciate any singular character at once. $\mathrm{He}$ had a clear head, as well as a benevolent heart; was a good man; an anxiously kind husband; an indulgent parent; and a sincere, forgiving friend; a just judge, and a punctual correspondent. I believed that he answered every letter sent to him, either from rich or poor, and generally not very shortly. Such is the man we have lost, and such a man we will never see again. He was truly an extraordinary man-the greatest man in the world. What are kings or emperors compared with him? Dust and sand! And, unless when connected with literary men, the greater part of their names either not remembered at all, or only remembered with detestation. But here is a name, which, next to that of William Shakespeare, will descend with rapt admiration to all the ages of futurity. And is it not a proud boast for an old shepherd, that, for thirty years, he could call this man friend, and associate with him every day and hour that he chose?

Yes, it is my proudest boast. Sir Walter sought me out in the wilderness, and attached himself to me before I had ever seen him, and, although I took cross fits with him, his interest in me never subsided for one day or one moment. He never scrupled to let me know 
that I behoved to depend entirely on myself for my success in life, but at the same time always assured me that I had talents to ensure that success, if properly applied and not suffered to run to waste. I was always received in his house like a brother, and he visited me on the same familiar footing. I never went into the inner house of Parliament, where he sat, on which he did not rise and come to me, and conduct me to a seat in some corner of the outer house, where he would sit with me two or three minutes. I am sorry to think that any of his relations should entertain an idea that Sir Walter undervalued me, for of all men I ever met with, not excepting the noblemen and gentlemen in London, there never was a gentleman paid more deference to me than Sir Walter; and though many of my anecdotes are homely and commonplace ones, I am sure there is not a man in Scotland who appreciates his value more highly or reveres his memory more.

With regard to his family, I have not much to say, for I know but little. Sophia was a baby when I first visited him, about two or three months old, and I have watched her progress ever since. By the time she had passed beyond the years of infancy, I perceived that she was formed to be the darling of such a father's heart, and so it proved. She was a pure child of nature, without the smallest particle of sophistication in her whole composition. And then she loved her father so! $\mathrm{O}$ ! how dearly she loved him! I shall never forget the looks of affection that she would throw up to him as he stood leaning on his crutch, and hanging over her at the 
harp, as she chaunted to him his favourite old Border Ballads, or his own wild Highland gatherings. Whenever he came into a room where she was, her countenance altered, and she often could not refrain from involuntary laughter. She is long ago a wife and mother herself, but I am certain she will always cherish the memory of the most affectionate of fathers.

Walter is a fine manly, gentlemanly fellow, without pride or affectation, but without the least spark of his father's genius that I ever could discern, and for all the literary company that he mixed with daily in his youth, he seemed always to hold literature, and poetry in particular, in very low estimation. He was terribly cast down at his father's death. I never saw a face of such misery and dejection, and though I liked to see it, yet I could not help shedding tears on contemplating his features, thinking of the jewel that had fallen from his crown.

I always considered Anne as the cleverest of the family; shrewd, sensible, and discerning, but I believe a little of a satirist, for I know that, when a mere girl, her associates were terrified for her. Charles is a queer chap, and will either make a spoon or spoil a good horn.

Of Lockhart's genius and capabilities, Sir Walter always spoke with the greatest enthusiasm, more than I thought he deserved, for I knew him a great deal better than Sir Walter did, and whatever Lockhart may pretend, I knew Sir Walter a thousand times better than he did. There is no man now living who knew Scott's character so thoroughly in all its bearings as 
William Laidlaw did. He was his land steward, his amanuensis, and managed the whole of his rural concerns and improvements for the period of twenty years, and sorry am I that the present Sir Walter did not find it meet to keep Laidlaw on the estate, for, without him, that dear-bought and classical property will be like a carcase without a head. Laidlaw's head made it. $\mathrm{He}$ knows the value of every acre of land on it to a tithe, and of every tree in the forest, with the characters of all the neighbours and retainers. He was, to be sure, a subordinate, but Sir Walter always treated him as a friend, inviting Mrs. Laidlaw and him down to every party where there was anybody he thought Laidlaw would like to meet, and Sir Walter called on Mrs. Laidlaw once or twice every day when he was in the country. I have seen him often pop in to his breakfast and take his salt herring and tea with us there with as much ease and good humour as if he had come into his brother's house. He once said to me as we were walking out about Abbotslee, and I was so much interested in the speech that I am sure I can indite it word by word, for Laidlaw was one of my earliest and dearest friends:

"Was it not an extraordinary chance for me that threw Laidlaw into my hands? Without Laidlaw's head I could have done nothing, and to him alone I am indebted for all these improvements. I never found a mind so inexhaustible as Laidlaw's. I have met with many of the greatest men of our country, but uniformly found that, after sounding them on one or two subjects, there 
their information terminated. But with the worst of all manners of expression, Laidlaw's mind is inexhaustible. Its resources seem to be without end. Every day, every hour, he has something new, either of theory or experiment, and he sometimes abuses me like a tinker because I refuse to follow up his insinuations."

Another day he said to me, "You know that I recommended your friend Laidlaw last year to Lord Mansfield as his factor, but was obliged to withdraw my recommendation, and give his lordship a hint to relinquish his choice. For, in the first place, I was afraid that Laidlaw's precarious health might unfit him for such a responsible situation; and, more than that, I found that I could not live without him, and was obliged, maugre all misfortunes, to replace him in his old situation." I therefore wish, from my heart and soul, that matters could have been so arranged that Laidlaw should not have been separated from Abbotsford; for though my own brother has long had and still has a high responsibility as shepherd and superintendent of the enclosures, I cannot see how the management of the estate can go on without Laidlaw. Under the law agents it will both cost more and go to ruin, and I say again, without Laidlaw, that grand classical estate is a carcase without a head.

Whenever Sir Walter spoke of either of his two sons, which he frequently did, it was always in a jocular way, to raise a laugh at their expense. His description of Walter, when he led in Mrs. Lockhart a bride, with his false mustachios and whiskers, was a source of endless 
amusement to him. He was likewise wont often to quote some of Charles's wise sayings, which, in the way that he told them, never failed to set the table in a roar of laughter.

Sir Walter had his caprices like other men, and when in poor health was particularly cross, but I always found his heart in the right place, and that he had all the native feelings and generosity of a man of true genius. I am ashamed to confess that his feelings for individual misfortune were far more intense than my own. There was one day that I went in to breakfast with him as usual, when he said to me, with eyes perfectly staring, "Good heaven! Hogg, have you heard what has happened?"

" Na, no that I ken o'. What is it that ye allude to, Mr. Scott?"

"That our poor friend Irving has cut his throat last night or this morning, and is dead."

" $O$, ay ! I heard $o$ ' that," said I, with a coldness that displeased him. "But I never heedit it, for the truth is that Irving was joost like the Englishman's fiddle; the warst fault that he had-he was useless. Irving could never have done any good either for himself, his family, or any other leevin' creature."

"I don't know, Mr. Hogg, what that poor fellow might have done, with encouragement. This you must at least acknowledge, that if he did not write genuine poetry, he came the nearest to it of any man that ever failed." These were Sir Walter's very words, and I record them in memory of the hapless victim of despair 
and disappointed literary ambition. He farther added, "For me, his melancholy fate has impressed me so deeply, and deranged me so much, that it will be long before I can attend to anything again."

$\mathrm{He}$ abhorred all sorts of low vices and blackguardism with a perfect detestation. There was one Sunday, when he was riding down Yarrow in his carriage, attended by several gentlemen on horseback, and I being among them went up to the carriage door, and he being our Sheriff I stated to him with the deepest concern that there was at that moment a cry of murder from the Broadmeadows Wood, and that Will Watherston was murdering Davie Brunton. "Never you regard that, Hogg," said he, with rather a stern air, and without a smile on his countenance. "If Will Watherston murders David Brunton, and be hanged for his crime, it is the best thing that can befall to the parish-drive on, Peter."

He was no great favourer of sects, and seldom or never went to church. He was a complete and finished aristocrat, and the prosperity of the state was his great concern, which prosperity he deemed lost unless both example and precept flowed by regular gradation from the highest to the lowest. He dreaded religion as a machine by which the good government of the country might be deranged, if not uprooted. There was one evening when he and Marrit of Rokeby, some of the Fergusons, and I, were sitting over our wine, that he said, "There is nothing that I dread so much as a very religious woman; she is not only a dangerous person, 
but a perfect shower-bath on all social conviviality. The enthusiasm of our Scottish ladies has now grown to such a height that I am almost certain it will lead to some dangerous revolution in the state. And then, to try to check it would only make the evil worse. If you ever choose a wife, Hogg, for goodness' sake, as you value your own happiness, don't choose a very religious one."

He had a settled impression on his mind that a revolution was impending over this country, even worse than we have experienced, and he was always keeping a sharp look-out on the progress of enthusiasm in religion as a dangerous neighbour. There was one day that he and Laidlaw were walking in the garden at Abbotsford, during the time that the western portion of the mansionhouse was building. The architect's name, I think, was Mr. Paterson.

"Well, do you know, Laidlaw," said Scott, "that I think Paterson one of the best natured, shrewd, sensible fellows that I ever met with. I am quite delighted with him, for he is a fund of continual amusement to me. If you heard but how I torment him! I attack him every day on the fundamental principles of his own art. I take a position which I know to be false, and persist in maintaining it, and it is truly amazing with. what good sense and good nature he supports his principles. I really like Paterson exceedingly."

"O he's a verra fine fellow," said Laidlaw. "An extraordinar fine fellow, an' has a great deal o' comings an' gangings in him. But dinna ye think, Mr. Scott, that it's a great pity he should hae been a preacher?" 
"A preacher?" said Scott, staring at him, "Good Lord! what do you mean?"

"Aha! it's a' ye ken about it!" said Laidlaw, "I assure you he's a preacher, an' a capital preacher too. He's reckoned the best Baptist preacher in a' Galashiels, an' preaches every Sunday to a great community o' low kind o' folks."

On hearing this, Sir Walter (then Mr. Scott), wheeled about and halted off with a swiftness Laidlaw had never seen him exercise before, exclaiming vehemently to himself, "Preaches! D- him!" From that time forth his delightful colloquies with Mr. Paterson ceased.

There was another time at Abbotsford, when some of the Sutherland family (for I don't remember the English title) and many others were there, that we were talking of the Earl of Buchan's ornamental improvements at Dryburgh, and, among other things, of the colossal statue of Wallace, which I rather liked and admired, but which Sir Walter perfectly abhorred, he said these very words. "If I live to see the day when the men of Scotland, like the children of Israel, shall every one do that which is right in his own eyes, which $I$ am certain either $I$ or my immediate successors will see, I have settled in my own mind long ago what I shall do first. I'll go down and blow up the statue of Wallace with gunpowder. Yes, I shall blow it up in such a style that there shall not be one fragment of it left! The horrible monster!" He had a great veneration for the character of Sir William Wallace, and I have 
often heard him eulogise it. He said to me one morning long ago, when Miss Porter's work, "The Scottish Chiefs," first appeared, "I am grieved about this work of Miss Porter! I cannot describe to you how much I am disappointed, I wished to think so well of it; and I do think highly of it as a work of genius. But, Lord help her! her Wallace is no more our Wallace than Lord Peter is, or King Henry's messenger to Percy Hotspur. It is not safe meddling with the hero of a country; and, of all others, I cannot bear to see the character of Wallace frittered away to that of a fine gentleman."

Sir Walter was the best formed man I ever saw, and, laying his weak limb out of the question, a perfect model of a man for gigantic strength. The muscles of his arms were prodigious. I remember of one day long ago, I think it was at some national dinner in Oman's Hotel, that at a certain time of the night a number of the young heroes differed prodigiously with regard to their various degrees of muscular strength. A general measurement took place around the shoulders and chest, and I, as a particular judge in these matters, was fixed on as the measurer and umpire. Scott, who never threw cold water on any fun, submitted to be measured with the rest. He measured most round the chest, and, to their great chargin, I was next to him, and very little short. But when I came to examine the arms, Sir Walter's had double the muscular power of mine, and very nearly so of every man's who was there. I declare, that from the elbow to the shoulder, they felt as if he had the strength of an ox. 
There was a gentleman once told me that he walked into Sir Walter's house, in Castle Street, just as the footman was showing another gentleman out, and that, being an intimate acquaintance, he walked straight into Sir Walter's study, where he found him stripped, with his shirt sleeves rolled up to his shoulders, and his face very red. "Good heaven, Scott, what is the matter?" said the intruder. "Pray, may I ask an explanation of this?" "Why, the truth is, that I have just been giving your friend, Mr. Martin, a complete drubbing," said Scott laughing. "The scoundrel dared me to touch him but with one of my fingers; but if I have not given him a thorough basting, he knows himself. $\mathrm{He}$ is the most impudent and arrant knave I ever knew. But I think it will be a while before he attempts to impose again upon me." This Mr. Martin, the gentleman said, was some great picture dealer. But as I never heard Sir Walter mention the feat in his hours of hilarity, I am rather disposed to discredit the story. He was always so reasonable, so prudent, that I hardly think he would fall on and baste even a knavish picture dealer black and blue, and in his own study. The gentleman who told me this is alive, and will, and may, answer for himself in this matter.

Sir Walter in his study, and in his seat in the Parliament-house, had rather a dull, heavy appearance, but in company his countenance was always lighted up, and Chantrey has given the likeness of him there precisely. In his family he was kind, condescending, and attentive, but highly imperative. No one of them 
durst for a moment disobey his orders, and if he began to hang down his eyebrows, a single hint was enough. In every feature of his face decision was strongly marked. He was exactly what I conceive an old Border Baron to have been, with his green jacket, his blue bonnet, his snow-white locks, muscular frame, and shaggy eyebrows.

He was said to be a very careless composer, yet I have seen a great number of his manuscripts corrected and enlarged on the white page which he alternately left, a plan which I never tried in my life. He once undertook to correct the press for a work of mine, "The Three Perils of Women," when I was living in the country, and when I gave the manuscript to Ballantyne, I said, "Now you must send the proofs to Sir Walter, he is to correct them for me."

"He correct them for you!" exclaimed Ballantyne, "Lord help you and him both! I assure you if he had nobody to correct after him, there would be a bonny song through the country. He is the most careless and incorrect writer that ever was born, for a voluminous and popular writer, and as for sending a proof sheet to him, we may as well keep it in the office. He never heeds it. No, no, you must trust the correction of the press to my men and me, I shall answer for them, and if $I$ am in a difficulty at any time, I'll apply to Lockhart. He is a very different man, and has the best eye for a corrector of any gentleman corrector I ever saw. He often sends me an article written off-hand like your own, without the interlineation of a 
word, or the necessity of correcting one afterwards. But as for Sir Walter, he will never look at either your proofs or his own, unless it be for a minute's amusement."*

The Whig ascendency in the British Cabinet killed Sir Walter. Yes, I say and aver, it was that which broke his heart, deranged his whole constitution, and murdered him. As I have shown before, a dread of revolution had long preyed on his mind; he withstood it to the last; he fled from it, but it affected his brain, and killed him. From the moment he perceived the veto of a democracy prevailing, he lost all hope of the prosperity and ascendency of the British Empire. He not only lost hope of the realm, but of every individual pertaining to it, as my last anecdote of him will show, for though I could multiply these anecdotes and remarks to volumes, yet I must draw them to a conclusion. They are trivial in the last degree, did they not relate to so great and so good a man. I have depicted him exactly as he was, as he always appeared to me, and was reported by others, and I revere his memory as that of an elder brother.

The last time that I saw his loved and honoured face was at the little inn on my own farm, in the autumn of 1830. He sent me word that he was to pass on such a day, on his way from Dumlanrig Castle to Abbotsford, but he was sorry he could not call at Altrive to see Mrs. Hogg and the bairns, it being so far off the way.

* This must have been “leein' Johnnie." See ante p. 98. 
I accordingly waited at the inn, and handed him out of the carriage. His daughter was with him, but we left her at the inn, and walked slowly down the way as far as Mountbenger-Burn. He then walked very ill indeed, for the weak limb had become almost completely useless, but he leaned on my shoulder all the way, and did me the honour of saying that he never leaned on a firmer or a surer.

We talked of many things, past, present, and to come, but both his memory and onward calculation appeared to me then to be considerably decayed. I cannot tell what it was, but there was something in his manner that distressed me. He often changed his subject very abruptly, and never laughed. He expressed the deepest concern for my welfare and success in life, more than I had ever heard him do before, and all mixed with sorrow for my worldly misfortunes. There is little doubi that his own were then preying on his vitals. He told me that which I never knew nor suspected before; that a certain gamekeeper, on whom he bestowed his maledictions without reserve, had prejudiced my best friend, the young Duke of Buccleuch, against me, by a story, and though he himself knew it to be a malicious and invidious lie, yet seeing his Grace so much irritated he durst not open his lips on the subject, farther than by saying, "But, my lord Duke, you must always remember that Hogg is no ordinary man, although he may have shot a stray moorcock." And then, turning to me, he said, "Before you had ventured to give any saucy language to a low scoundrel of an English gamekeeper, 
you should have thought of Fielding's tale of Black George."**

"I never saw that tale," said I, "an' dinna ken ought about it. But never trouble your head about the matter, Sir Walter, for it is awethegither out o' nature for our young chief to entertain ony animosity against me. The thing will never mair be heard of, an' the chap that tauld the lees on me will gang to hell, that's aye some comfort."

I wanted to make him laugh, but I could not even make him smile. "You are still the same old man, Hogg, careless and improvident as ever," said he, with a countenance as gruff and demure as could be.

Before we parted I mentioned to him my plan of trusting an edition of my prose tales, in twenty volumes, to Lockhart's editing. He disapproved of the plan decidedly, and said, "I would not for anything in the world that Lockhart should enter on such a responsibility, for, taking your random way of writing into account, the responsibility would be a very heavy oneay, and a dangerous one too!" Then, turning half round, leaning on his crutch, and fixing his eyes on the ground for a long space, he said, "You have written a great deal that might be made available, Hogg, with proper attention, and I am sure that one day or other, it will be made available to you

* And yet Scott conld bow down and worship this boy idiot-the plaything of a rascally gamekeeper-who valued a moorfowl more than a poet-because he was a Duke! 
or your family, but, in my opinion, this is not the proper season. I wish you could drive off the experiment until the affairs of the nation are in better keeping, for at present all things, and literature in particular, are going straight down-hill to destruction and ruin." And then he mumbled something to himself, which I took to be an inward curse. I say again, and I am certain of it, that the democratic ascendency, and the grevious and shameful insults he received from the populous of his own country, broke the heart of and killed the greatest man that ever that country contained.*

When I handed him into the coach that day, he said something to me which, in the confusion of parting, I forgot; and though I tried to recollect the words the next minute, I could not, and never could again. It was something to the purport that it was likely it would be long ere he leaned as far on my shoulder again, but there was an expression in it, conveying his affection for me, or his interest in me, which has escaped my memory for ever.

This is my last anecdote of my most sincere and esteemed friend. After this I never saw him again. I called twice at Abbotsford during his last illness, but they would not let me see him, and I did not at all regret it, for he was then reduced to the very lowest state of weakness to which poor, prostrate humanity could be subjected. He was described to me, by one 
who saw him often, as exactly in the same state with a man mortally drunk, who could in nowise own or assist himself; the pressure of the abscess on the brain having apparently the same effect as the fumes of drunkenness. He could, at short intervals, distinguish individuals, and pronounce a few intelligible words; but these lucid glimpses were of short duration, the sunken eye soon ceased again from distinguishing objects, and the powerless tongue became unable to utter a syllable, though constantly attempting it, which made the sound the most revolting that can be conceived.

I am sure heaven will bless Lockhart for his attention to the illustrious sufferer. The toil and the watching that he patiently endured, one would have thought was beyond human nature to have stood, and yet I never saw him look better or healthier all the while. He will not miss his reward. I followed my friend's sacred remains to his last narrow house, remained the last man at the grave, and, even then, left it with reluctance.

Omnes eodem cogimur: omnium

Versatiur urna, serius, ocyus

Sors exitura.*

* Saul among the prophets! Hogg quoting Latin! 

MEMOIR: LIFE OF THE ETTRICK SHEPHERD.

"Adam Blair," 39

Aikman, 27

Alexandrine, 34

Altrive, 34,35

Annandale, 43

"Annuals," 43

Athol, 33

"Auld Maitland," I4

"Autobiography," 37

Ayrshire bard, I9

Bacchanalian Club, 37

Bible, authorised version, 4I

"Bird of the wilderness," 49

Blackhouse, I6, 19, 22

"Blackwood," 4I, 42

Blackwood, 33, 34, 40, 4I, 44

Blind Harry's "Wallace," I6

"Bonnie Kilmeny," 22, 28

"Bonnie Prince Charlie," 49

Border, 10, I3, 14

Boston, Thomas, I4

"Brownie of Bodsbeck, The," 38

Buccleuch, Duke of, 34

Burns, Robert, I8, 44, 45, 46, 47, 49

Byron, Lord, 35

Carlisle, $12,3 \mathrm{I}$

Chapelhope, 38,39

Charlotte, Princess, 28

"Chaldee Manuscript," 4I

"Christopher North," 40

Claverhouse, 38

Cleghorn, 40, $4 \mathrm{I}$

Cochrane, 44, 45, 47, 48

Coleridge, 36

"Confessions of a Fanatic, The," 39

Constable, 23, 25, 27, 28, 33, 34

Correggio, 19

Covenanter, 38,39

Cowgate, 26, 3 I

Crown Tavern, 20

Cunningham, Allan, 23

Daebeth, 17

Dalkeith, Countess of, 25

Daniel, book of, 4I

"Donald Macdonald," 19, 2I

Dumfriesshire, 25

Duneira's men, 28
"Eclectic," 28, 34

Edinburgh, 20, 2I, 23, 25, 26, 35

"Edinburgh Monthly Magazine,"

"Editor's Narrative," 39 [40, 4 I

Episcopalian party, $3^{8}$

Ettrick, 9, 10, I r, 14, 15, 22, 25, 48

Ettrick Forest, 9

Ettrickhall, I2

Ettrickhouse, I 2

Flodden, 9

"Floo'rs o' the Forest," 9

"Forest Minstrel," 25

"Forum," 27, 28

France, 27

French Revolution, 29

Fullarton, 45

Glasgow, 47

Goldie, 28, 33

"Good principles and good breed-

Government, 40 [ing," 47

Graham of Claverhouse, 39

Grieve, 27

Guardian of the Realm, 9

"Gude Greye Katte, The," 36

Hamilton, John, 20

Harkness of Mitchelslack, 22

Harris, 22

Highlands, 22, 40

Hoggs of Fauldshope, 12

Hogg, Mrs., I4, 43

Hogg, Robert, 12

Innerleithen, 17

Ireland, 14

"Isle of Palms, The," 49

Izett of Kinnaird, 33

"Jacobite Relics of Scotland," 40

Jamie Battie, 17

"Jamie the Poeter," I7

Kilmeny, 28, 29, 30, 40

Kinnaird House, 33

Lady Scott, 46

Laidlaw, 16, 19, 24

Laidlaw, Margaret, 12 
Laidlaw, William, 14, 16

Lanarkshire, I7

Land of Faëry, 29

Lang, Andrew, 38

"Lara," 35

"Lay Sermons," 47

" Life of Burns," 45

Loch Leven, 32

Lockhart, 23, 24, 39, 40, 4I, 46,

Lomond, 3 I, 32

London, 44, 47

MacDonald, General, 20

"Macmillan's Magazine," 39

"Mador of the Moor," 33, 34

Malcolm, Sir John, 44

Miller, 34

"Minstrelsy of the Scottish Border,

Mitchelslack, 22

M'Neill, John, 47

Moira, Earl of, 20

Montrose, Io

"Montrose Tales," 47, 48

Motherwell, 45, 47

Mount Benger, 35

Mure, Elizabeth, 33

Murray, 34

Napier of Merchiston Hall, II

Nithsdale, 22

“Noctes Ámbrosianæ," 26, 42, 43, 49

" Old Ebony," 4I

Oliver, Mr., 20

"Old Mortality," 38, 39

Parish of Ettrick, 10

Parliament-house, 4I

"Pedlar," 14, 24

Philiphaugh, 9

Phillips, Margaret, 43

"Pilgrims of the Sun, The," 34

Plato, I7

"Poetic Mirror," 36

Potts, I 5

Prince Charlie, 40

Princess Charlotte, 28

Pringle, 40, 4I, 42

Psalms, I4

“Queen Hynde," 37, 38

Queen Mary, 27

Queen of Faery, 9
Queensberry Hill, 22

"Queen's Wake," 27, 28, 30, 32, 33,

$[34,38$

Ramsay's "Gentle Shepherd," I6

Raphael, 19

"Rejected Addresses," 36

" Relics," 40

Rembrandtesque, 26

Reid, 46

Robert II., 33

Robertson, 26, 3 I

Russell, Rev. Robert, IO, II, I 5, I7

Saintsbury, Professor, 39

Scandinavian, 12

Scotland, 9, 14, 20, 45, 50

Scott, John, i8

Scott, Mrs., 23

Scott, Sir Walter, 10, $21,22,23$, $31,36,37,3^{8}, 40,42,43,45$, $46,47,49$

Scotts of Harden, 12

Scriptures, 13

Selkirk, II

Selkirkshire, 9

"Sermons," 47

Socrates, 43

Southey, 36, 48, 49

Spenserian stanza, 34

Spurgeon, 47

$S p y, 26,27,40$

"Statistical Account of Scotland," I0

St. Boswells, 12

Stirling Bridge, 9

St. Mary's Kirk, 9

Sym, Robert, 27

“Tam o' Shanter," I8

"The Mountain Bard," 23, 24, 25

"The Shepherd's Guide," 24

"The Woolgatherer," 50

"Timothy Tickler," 27

"Twa Corbies," 23

Tweed, 10

Veitch, Professor, 12

Wallace, 9

"Wallace Wight," 14

Washington Irving, 10

"Waterloo, The Field of," 43

"Wattie," 23, 24

Waverley Novels, 38

"When the kye comes hame," 49 
Will o' Phaup, 14

Wilson, John, 40, 42, 43, 48

"Witch of Fife, The," 30

"Wizard," 22
Wordsworth, 9, 36

Yarrow, 9, 10

"Yarrow Revisited," 9

\section{DOMESTIC MANNERS OF SIR WALTER SCOTT.}

Abbotsford, 64, 66, 81, 86, 89, 107, I IO, III, II 5, I 8

Abbotslee, 106

Addison, 90

Albemarle Street, 79

Allan Cunningham, 93

Altrive, II 5

Anne, 82, 105

Ashiesteel, 60, 83

Ballantyne, 68, 95, 96, 98, Ballantyne, James, 75, 77, 82, 99

Ballantyne, Johnnie, 55, 72, 74, 85,

Baubie Mettlin, 52

Berwick, 82

Black Dwarf, 95

Black George, 1 i 7

Blackwood, 76

Border, 68, I05, II 4

Bowhill, 63, 67

Boyd, Mr., 91

Britain, 72, 74, 82

"Brownie of Bodsbeck," 75

Brougham, 8o

Broadmeadows, 90

Brydon, 53, 54, 57

Buccleuch, 55, 56, 62, 63, 70

Buccleuch, Duke of, 116

Buchan, Earl of, I I I

Burns, Captain J. G., 93

Cadell, 58

Calton Hill, 96, 97

Carlisle, 102

"Castle Dangerous," 78

Castle Street, 66, 7 I, I I3

Castle Weiry, 69

Charlotte Square, 88

Chantrey, II 3

Chisholme, Peter, 69

Clavers, 60

Cooper of Fogo, 87

Court of Session, 96

Corduroy, Christopher, 85

Covenanter, 77

Crosslee, 57
Cumberland, 8I

Curwin, 8I

Derwent, 8I

"Domestic Manners of Sir Walter Scott," 22, 24, 45, 46, 47

Donachie, 94

Don, Sir Alexander, 67, 68

Dryburgh, 66, I I I

Duke Charles, 63

Dumlanrig Castle, II 5

Edinburgh, 57, 64, 66, 69, 79, 83, 94

"Edinburgh Annual Register," 72,74

Eildon, Hunt of, 78

Erskine, William, 82, 99

Ettrick, 91, 92

Ettrick Forest, 54, 79

Ettrickhouse, 5 I

Falconbridge, 82

Ferguson, Col., 88

Ferguson, Sir Adam, 6o, 63

Ferrier's Novels, 99

Fielding, I 17

Firth of Forth, 59

Forest, 6r

Galashiels, I I I

Gillies, Mr., 95, 96

"Gilman's-cleuch," 58

Gleddie's Weal, 59

"Glenfinlas," 82

Gordons, 77

Grey-mare's-tail, 60

Grieve, 83

"Guy Mannering," 97

Haliburton, 62

Harden, 62, 63

Hoggs of Fauldshope, 63,64

Hogg, 58, 69, 71, 72, 75, 76, 84, $85,87,89,93,96,98$, IоI, I08, I 10, I 6 , I I 7, I 18 , I 19

Hogg, Mrs., 86, I I 5

Holland, Lord, 67

Hope, Sir John, 84 
Jeffrey, 80, 8I

Johnson, 90

Keswick, 8r

Kineder, Lord, 82

Lady Scott, 60, 80, 81, 82

"Lady of the Lake, The," 84, 96, 97

Laidlaw, 53, 54,56, 107, I I , I I I

Laidlaw, Margaret, 87

Laidlaw, Mrs., 106

Laidlaw of the Peel, 59

Laidlaw, William, 52, 60, 106

Lasswade, 79

Laurieston, 88

"Lay of the Last Minstrel, The," 82

Lewis, 85,

Loch-Skene, 60

Lockhart, 85, 100, 105, I14, I17,

Lockhart, Hugh John, 89 [119

London, 79, 83, 104

Mainsforth, 83

Maitland Street, 88

Mansfield, Lord, 107

"Marmion," 80, 81, 83, 97

Marrit, Jo9

Martin, Mr., I 13

Maturin, Ior

M'Corkingdale, Daniel, 99

Melrose, 66

"Minstrelsy of the Border, The," 52

Milsey Bog, 57

$M '$ Kenzie, Hugh, 90

Moffat, 60

Moor, Andrew, 52

Morison, 83, 84

Mount Benger, 87

Mountbenger-Burn, 116

Mount Comyn, 55

Murray, John, 79

Nithsdale, 90

North Bridge, 96

North Esk, 79

Ogg, Mr., 80

Old Maitlan', 52

"Old Mortality," 77, 97

Old Nanny, 77

Paris, 89

Parliament, 104
Parliament-house, 66, 75, 95, II 3

Paterson, Mr., I IO, III

Pechs (Picts), 57

Porchester, Lord, 9I

Porter, Miss, II 2

Queensberry, Marquis of, 68

"Queen's Wake," 9I

Ramsey-cleuch, 5I, 52, 53

Rankleburn, 55

Robertson, Mr., 94

Rob Fletcher, 58, 59

Rokeby, 83, 109

Rough Haugh of Elibank, $5^{8}$

Rutherford, 62

Satchells, 55

Scotland, 104

Scott, Mrs., 79, 8o

Scott of Harden, 64

Shakespeare, William, 103

Sharpe, Kirkpatrick, 102

Sharpe, Sir C., 95

Shuffleton, 73

Skene of Rubislaw, $5^{8}$

Sophia, 60, 104

Southey, 59, 72, 74, 81, 98

$S p y, 71,72,73,74,89$

St. Andrew's Square, 95

Stewart, James, 53

"St Mary's Lake," 83

Sutherland family, I I I

Terry, 96

"The Mountain Bard," 6r

"The Scottish Chiefs," I 12

Thirlstane, 57

"Three Perils of Man, The," 68, 78

"Three Perils of Women, The," 114

Tushielaw, 52, 53, 57

Tweed, 57, 58, 59, 60

Wallace, I I I, I I 2

Wallace, Mr., of Kelly, 96

Warton, George, 53

Wat Shiel, 5 I

"Witch of Fife, The," 102

Wordsworth, 53

Yarrow, 66, 91, 109

York Place, 95 




\section{VICTORIA UNIVERSITY PRATT LIBRARY \\ 585-4470}

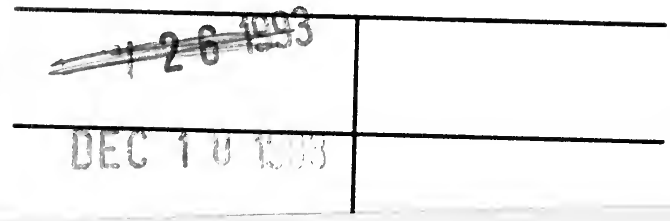


